\title{
Sağlık Hizmetleri Meslek Yüksekokulu Öğrencilerinin Sosyal Kaygıları ve Genel Öz-Yeterlik Algılarının Çeşitli Değişkenler Açısından İncelenmesi*
}

Aysel ARSLAN ${ }^{1}$

$\ddot{\mathbf{O ̈ z}}$

Bu çalışmanın amacı; Sağlık Hizmetleri Meslek Yüksekokulu (SHMYO) öğrencilerinin sosyal kaygıları ve genel özyeterlik algılarının cinsiyet, gelir düzeyi, ikamet yeri, mezun olunan okul türü ve branş değişkenleri açısından incelenmesi ve aralarındaki korelasyonun belirlenmesidir. Araştırmanın örneklem grubunu 2018-2019 eğitim-öğretim y1lı bahar döneminde Sivas Cumhuriyet Üniversitesi SHMYO'da eğitim görmekte olan 670 kız, 201 erkek olmak üzere toplamda 871 öğrenci oluşturmaktadır. Araştırma verileri ilişkisel tarama modeli kullanılarak elde edilmiştir. SHMYO öğrencilerinin sosyal kaygı düzeylerinin belirlenmesi amacıyla Özbay ve Palancı (2001) tarafindan geliştirilen "Sosyal Kaygl Ölçeği”" kullanılmıştır. Öğrencilerin genel öz-yeterlik algılarını belirlemek amacıyla; Sherer, Maddux, Mercandante, Dunn, Jacobs ve Rogers (1982 tarafindan geliştirilen Türkçeye uyarlaması Yıldırım ve İlhan (2010) tarafindan yapılan "Genel Öz-yeterlik Ölçeği Smirnov (K-S), aritmetik ortalama, standart sapma, bağımsız t testi, ANOVA, LSD, Pearson korelasyon katsayıs1 kullanılmıştır. Öğrencilerin sosyal kaygı düzeylerinin gelir düzeyi, ikamet yeri, mezun olunan lise türü ve branş; özyeterliklerinin gelir düzeyi, mezun olunan lise türü ve branş değişkenlerine göre anlamlı farklılık gösterdiği, sosyal kaygı ve öz-yeterliklerinin negatif yönde orta düzeyde (.-42) bir ilişki gösterdiği belirlenmiştir.

Anahtar kelimeler: Kaygı, sosyal kaygı, öz-yeterlik, öğrenci, üniversite

\section{$\underline{\text { Research Article }}$}

\section{Study of Social Anxiety and Self-Sufficiency Perceptions of Health Services Vocational School Students from the Point of Various Variables}

\begin{abstract}
It is aimed to determine whether there is a significant difference in the social anxiety and self-efficacy perceptions of the Vocational School of Health Services students in terms of gender, income level, place of residence, type of graduated high school and branch of education, in this study. The sample of the research is constituted by 871 students in total, comprising 670 girls and 201 boys, being education in Health Services Vocational School of Sivas Cumhuriyet University in the spring period of 2018-2019 education- training year. Social anxiety scale was developed by Özbay and Palanc1 (2001), was used for the collection of data for research. In order to determine the self-efficacy perceptions of the students, the "General Self-Efficacy Scale" developed by Sherer, Maddux, Mercandante, Dunn, Jacobs and Rogers (1982) and adopted to Turkish by Yildirım and İlhan (2010), was used. The data related to the research was analyzed using Kolmogorov-Smirnov (K-S), arithmetic average, standard deviation, independent $t$ test, ANOVA, LSD, Pearson correlation coefficient. It was concluded that the social anxiety of the students were significantly different by the income level, place of residence, type of graduated high school and branch variables; the self-efficacy perceptions of the students were significantly different by income level, income level and branch variables. Besides, it was determined that total score correlations of the writing anxiety and self-efficacy perceptions of the students were at medium level in negative direction (-.42).
\end{abstract}

Keywords: Anxiety, social anxiety, self-efficacy, student, university

To cite this article: Arslan, A. (2019). Sağlık hizmetleri meslek yüksekokulu öğrencilerinin sosyal kaygıları ve genel özyeterlik algılarının çeşitli değişkenler açısından incelenmesi. International e-Journal of Educational Studies (IEJES), 3 (6), 78-96. DOI: 10.31458/iejes.524860

${ }^{1}$ Lecturer, Cumhuriyet University, Sivas, Turkey

Corresponding Author e-mail address: arslanaysel.58@gmail.com 


\section{GíRiș}

Kaygi; nedeni tam olarak bilinmeyen ancak bireyi huzursuz ve tedirgin eden, korku, endişe ve s1kıntı olarak gözlenen, bireyin gerçekleşmesini engelleyemeyeceği kötü bir olayın olacağına ilişkin düşünce olarak tanımlanmaktadır (Anthony \& Swinson, 2000). Düşük düzeydeki kaygı sosyal hayatın doğal bir sonucu olarak var olduğu (Baumeister \& Tice, 1990); kendini geliştirip başarılı olması için gerekli olan performansını artırdığı, başarıya ilişkin güdülediği (Işık, 1996) için bireyin hayatını sürdürmesinde gerekli görülmektedir (Hamarta, 2009). Kaygı kavramı alan yazında kaygı bozukluğu, obsesif kompülsif bozukluk, panik bozukluk, farklı alanlara yönelik fobi vb. adlarla yer almaktadır. Kaygı, kendi içinde de hissedildiği alana yönelik olarak konuşma kaygısı (Arslan, 2018a), okuma kaygısı (Arslan, 2017a), sosyal kaygı gibi pek çok alt kavramlara ayrılmaktadır (Dunlop, Papp, Garlow, Weiss, Knight \& Ninan, 2007).

Sosyal kayg1; bireyin tanımadığı bir topluluk içinde yer aldığı zaman yaptığı eylemlerin ve davranışların sürekli birileri tarafindan gözlendiğini, küçük düşecek ve utanılacak bir hareket yapacağına inanmasından kaynaklanmaktadır (Leahy \& Holland, 2009). Birey, tanımadığı bir çevrede sosyal kaygıyı yoğun olarak yaşamakla birlikte tanıdığı ortamlarda da benzer duygular yaşamaktadır. Sosyal kaygıyı Beck (2005), bir toplulukta kendinin ilgi odağı olacağı ve yaptıklarının başkalarınca gözlemlenerek olumsuz değerlendirileceğine inanması; Davison ve Neale (2004), başkalarının olduğu ortamlarda hissettiği, mantıklı bir açıklaması olmayan korku şeklinde tanımlamaktadır. Birey, toplum içinde hissettiği yoğun kaygı neticesinde başkalarının yanında yemek yeme, konuşma, alışveriş yapma, yazı yazma, eğlenme vb. pek çok konuda performans sergilerken rahat olamamaktadır (Davison \& Neale, 2004). Bu açıdan bakıldığında sosyal kaygı bireyin hayatında pek çok konuda oldukça sınırlandırıcı ve diğer bireylerden kendini izole etmesine neden olan, zaman içinde süreklilik kazanan bir bozukluk olarak görülmektedir (Erözkan, 2004).

Sosyal kaygı genel olarak ergenliğin başlangıcı olarak sayılan 11-15 yaş aralığında ortaya çıkmasına karşın daha erken ya da daha geç yaşlarda da görülebilmektedir (Leahy \& Holland, 2009). Ergenlik döneminde bireyin yaşadığı değişimler sonucunda kendine yönelik algısının oldukça hassas olması, sosyal ortamlarda yaşadığı olumsuz deneyimler, ebeveynleriyle yaşadıkları sorunlar sonucunda yaşadığı özgüven eksikliği sosyal kaygı yaşamasına temel neden olmaktadır (Hamarta, 2009). Birey bu dönemde yaşadığı yoğun sosyal kaygıyı azaltabilmek, kontrol altına alabilmek için olumsuz tutum ve davranışlar gösterebilmektedir. Gösterdiği olumsuz tutum ve davranışlar neticesinde sürekli eleştirilen birey kendini yetersiz hissetmekte, sosyal ortamlara katılmayı reddetmekte ve süreç içerisinde süreklilik kazanmaktadır. Girdiği ortamlarda kaygı yaşayan ve tedirgin olan bireyin bu duygusu, ergenlikten sonraki dönemlerinde de devam etmektedir. Bireyin yaşadığı sosyal kaygının azaltılmasında, çevresindeki kişilerce kabul görmesi, anlaşılması ve desteklenmesi oldukça önemli olmaktadır. Bireyin yaşadığı kaygı durumuyla baş edebilmesinde önemli bir diğer etken de kendine yönelik olumlu algısının geliştirilmesi (Temel \& Aksoy, 2001), yapabileceklerinin ve yeterliklerinin farkında olmasıdır. Bandura (1997: 8), bireyin bilişüstü becerilerinin yüksek olmasının yaşadığı baskı, stres, kaygı, endişe vb. olumsuz duygularla başa çıkabilmesinde önemli olduğunu vurgulamaktadır.

Bilişüstü beceriler arasında yer alan öz-yeterlik, Bandura'nın geliştirdiği "Sosyal Bilişsel Kuram" içinde yer almaktadır. Bandura'nın kuramına göre bireyin tutum ve davranışları içinde bulunduğu çevre ve yaşadığı toplum ile sürekli bir etkileşim halinde bulunmaktadır. Bireyin yaşadığ bu etkileşim sonucunda her türlü olay ya da olguya yönelik olarak sergilediği davranış ve tutumu olumlu ya da olumsuz olarak şekillenmektedir (Bandura, 1986). Sosyal bilişsel kuram temelde, bireyin sahip olduğu yeterliklerin ortaya çıkması ve organizasyonu ile ilgili olup etkileşim, sonuç beklentisi ve öz-yeterlik olmak üzere üç temel kavramı içermektedir. Bu kavramlar, bireyin tüm davranışlarını şekillendiren ve yöneten mekanizmayı bilinçli olarak gerçekleştirilen davranışlar haline getirerek güçlendirmektedir (Pajares, 2006). Bireyin bir konuda sergilediği performansı bilişsel, davranışsal ve çevresel etkenlerle birleşerek belirli bir etkileşim sonucu ortaya çıkmaktadır (Bandura, 1997). Bu anlamda birey, yaşadığ toplumun sosyal sistemini hem etkileyen hem de sosyal sistemden etkilenen konumundadır (Bandura, 1986). Sonuç beklentisi, bireyin bir işi gerçekleştirmesi için göstermesi gereken çabayı, işin gerçekleşmesi durumunda ortaya çıkabilecek sonuçları ve değişimleri ifade etmektedir. Öz-yeterlik, sosyal bilişsel teorinin en önemli anahtar kavramı olarak ifade edilmektedir (Pajares, 2006). Öz-yeterlik, bireyin karşılaştığı durumları kontrol edebilmesi, performans düzeyine 
ilişkin inancı, herhangi bir işe yönelik olarak göstereceği performansa yönelik becerileri düzenlemesi ve sergilemesine ilişkin olarak kendi hakkındaki düşünceleri (Bandura, 1997) olarak tanımlanmaktadır. Genel olarak yapılan tanımlar değerlendirildiğinde öz-yeterlik: bireyin belirli bir davranış, görev ya da performansı gerçekleştirme becerisine ilişkin kendine yönelik algısı (Cassidy \& Eachus, 2002) şeklinde ifade edilebilir. Bireyin kendine yönelik algısı olumlu ve yüksek düzeyde ise performans sergileme yönünde de daha istekli ve başarılı olacağı belirtilmektedir (Pajares, 2006).

Öz-yeterlik algısının birbiri ile sürekli etkileşim halinde bulunan dört temel bilgi kaynağı bulunmaktadır (Yavuzer \& Koç, 2002: 35). Bu kaynaklardan ilki, bireyin daha önceden yaptığı işleri ve ulaştığı hedefleri içeren performans kaynakları; ikincisi, başka bireylerin deneyimleri sonucunda ulaştığı başarı ya da başarısızlıkları gözlemlemeyi ve bu doğrultuda kendi yapabilecekleri hakkında kestirimde bulunmayı içeren dolaylı yaşantılar; üçüncüsü, çevredeki kişilerin yaptığı olumlu ya da olumsuz telkinlerin etkisi ve cesaretlendirmesini içeren sözel ikna; sonuncusu ise duygusal ve bedensel durumun etkisini içeren duyuşsal ve fizyolojik süreçler olarak ifade edilmektedir (Bandura, 1997). Bu kaynaklar, tek başına bireyin öz-yeterlik algısını şekillendirmemekle birlikte içlerinde en etkili olanı bireyin bizzat deneyimlerine dayanan performans kaynaklarıdır. Öz-yeterlik algısını oluşturan kaynaklar birbirleriyle kurdukları etkileşim sonucunda bireyin öz-yeterlik algı düzeyine yönelik ortak bir yargının oluşmasını sağlamaktadır (Pajares \& Schunk, 2004). Bireyin öz-yeterlik algısında; sahip olduğu yetenekler, çaba düzeyi, performans beklenilen görevin ya da davranışın güçlük seviyesi, çevreden gelen destek vb. etkili olmaktadır (Çimen, 2007). Öz-yeterlik kavramının ortaya çıkmasından sonraki süreç içerisinde ilkokuma ve yazmaya etkisi (Akar, 2008), fen öğretimi öz-yeterliği (Akbaş \& Çelikkaleli, 2006), matematik öz-yeterliği (Aksu, 2008), akademik öz-yeterlik (Arslan, 2017b, 2018b), bilgisayar öz-yeterliği (Aşkar \& Umay, 2001) vb. pek çok farklı alanla bağlantısı kurulmuş ve bu alanlarla ilgili öz-yeterlik algıları araştırılmıştır. Ayrıca alan yazın incelendiğinde; öz-yeterliğin drama yöntemi (Altıntaş \& Kaya, 2012), konuşma kaygısı (Arslan, 2018a), yazma kaygısı (Arslan, 2018b), üstbilişsel okuma stratejileri (Koç \& Arslan, 2017) vb. olumlu ya da olumsuz kavramlarla ilişkisini araştıran çalışmalar olduğu görülmektedir. Sosyal kaygının yüksek olmasının bireyin toplum içindeki davranış, ilişki, iletişim ve performansı üzerindeki olumsuz; öz-yeterlik algısının yüksek düzeyde olmasının ise bireyin olumsuz tutum ve davranışları üzerinde olumlu etkisinin olduğu kabul edilmektedir. İlgili alan yazın incelendiğinde öz-yeterliğin sosyal kayg1 üzerindeki etkisi ve ilişkisini belirlemeye yönelik bir çalışmaya rastlanmamıştır. Bu doğrultuda bu çalışmada öz-yeterlik algısı ve sosyal kaygı arasındaki ilişkinin belirlenmesine karar verilmiştir. Yapılan bu araştırmada SHMYO öğrencilerinin öz-yeterlik algıları ve sosyal kaygılarının çeşitli demografik değişkenler açısından incelenmesi, aralarındaki ilişki düzeyinin belirlenmesi amaçlanmaktadır. Belirlenen amaca uygun olarak aşağıdaki soruların yanıtı aranmıştır:

- SHMYO öğrencilerinin sosyal kaygıları ve genel öz-yeterlik algılarına ilişkin puan ortalamaları ölçeklerin toplam puanları ve alt boyutlarında ne düzeydedir?

- SHMYO öğrencilerinin sosyal kaygıları cinsiyet, sınıf düzeyi, öğretim türü, mezun olunan lise türü, ailenin gelir düzeyi, ailenin ikamet yeri ve eğitim aldıkları branş değiş̧kenlerine göre anlamlı düzeyde farkl1l1k göstermekte midir?

- SHMYO öğrencilerinin genel öz-yeterlik algıları cinsiyet, sınıf düzeyi, öğretim türü, mezun olunan lise türü, ailenin gelir düzeyi, ailenin ikamet yeri ve eğitim aldıkları branş değişkenlerine göre anlamlı düzeyde farklılık göstermekte midir?

- SHMYO öğrencilerinin sosyal kaygıları ile akademik genel öz-yeterlik algıları arasında anlamlı bir ilişki bulunmakta mıdır?

\section{YÖNTEM}

$\mathrm{Bu}$ araştırmada tarama modelleri arasında yer alan basit seçkisiz tarama modeli kullanılmıştır.

\subsection{Evren/Örneklem}

Çalışmaya dâhil edilen örneklem grubu; 2018-2019 eğitim-öğretim yılı bahar döneminde Sivas Cumhuriyet Üniversitesi SHMYO'da eğitim görmekte olan 670 kız, 201 erkek olmak üzere toplamda 871 öğrenciden oluşmaktadır. Örneklem sayısını belirlemek için araştırmanın yapıldığı öğretim döneminde SHMYO'da eğitim görmekte olan 3.679 öğrenciden \pm .05 örneklem hatasına göre yeterli 
sayıda öğrenci (Sönmez \& Alacapınar, 2011: 338) araştırmaya gönüllü olarak katılmıştır. Tablo 1'de örnekleme ilişkin betimsel istatistikler sunulmaktadır.

Tablo 1. Örnekleme ilişkin demografik özellikler

\begin{tabular}{|c|c|c|c|}
\hline \multicolumn{2}{|l|}{ Değisşkenler } & \multirow{2}{*}{$\begin{array}{c}\text { Frekans (f) } \\
670\end{array}$} & \multirow{2}{*}{$\begin{array}{c}\text { Yüzde (\%) } \\
76.92\end{array}$} \\
\hline & Kiz & & \\
\hline Cinsiyet & Erkek & 201 & 23.08 \\
\hline \multirow{4}{*}{ Gelir Düzeyi } & Çok iyi & 22 & 2,26 \\
\hline & İyi & 279 & 32.03 \\
\hline & Orta & 533 & 61.19 \\
\hline & Düşük & 37 & 4.25 \\
\hline \multirow{4}{*}{ İkamet yeri } & Köy & 152 & 17.45 \\
\hline & İlçe & 191 & 21.93 \\
\hline & Şehir & 409 & 46.96 \\
\hline & Büyükşehir & 119 & 13.66 \\
\hline \multirow{5}{*}{$\begin{array}{l}\text { Mezun olunan lise } \\
\text { türü }\end{array}$} & Genel lise & 146 & 16.76 \\
\hline & İmam hatip lisesi & 73 & 8.61 \\
\hline & Mesleki teknik lise & 179 & 20.32 \\
\hline & Sağlık meslek lisesi & 231 & 26.52 \\
\hline & Anadolu lisesi & 242 & 27.78 \\
\hline \multirow{10}{*}{ Branş } & Fizyoterapi & 90 & 10.33 \\
\hline & Tibbi dok. ve sek. & 102 & 11.71 \\
\hline & Çocuk gelişimi & 210 & 24.11 \\
\hline & T1bbi gör. tek. & 52 & 5.97 \\
\hline & Yaşlı bakımı & 162 & 18.60 \\
\hline & İlk ve acil yardım & 104 & 11.94 \\
\hline & Eczane hizmetleri & 27 & 3.10 \\
\hline & Tibbi lab. tek. & 43 & 4.94 \\
\hline & Odyometri & 33 & 3.79 \\
\hline & Optisyenlik & 48 & 5.51 \\
\hline
\end{tabular}

Tablo 1'deki verilere göre araştırmanın örneklem grubunu 670 kız, 201 erkek öğrencinin oluşturduğu; öğrencilerden 22'sinin gelir düzeyinin çok iyi, 279'unun iyi, 533'ünün orta ve 37 öğrencinin düşük düzeyde olduğu; 152 öğrencinin köy, 191 öğrencinin ilçe, 409 öğrencinin şehir ve 119 öğrencinin ailesinin büyükşehirde yaşadığ $1 ; 146$ öğrencinin genel lise, 75 öğrencinin imam hatip lisesi, 177 öğrencinin mesleki teknik lise, 231 öğrencinin sağlık meslek lisesi ve 242 öğrencinin Anadolu lisesinden mezun olduğu; 90 öğrencinin fizyoterapi, 102 öğrencinin tıbbi dokümantasyon ve sekreterlik, 210 öğrencinin çocuk gelişimi, 52 öğrencinin tıbbi görüntüleme teknikleri, 162 öğrencinin yaşlı bakımı, 104 öğrencinin ilk ve açıl yardım, 27 öğrencinin eczane hizmetleri, 43 öğrencinin tıbbi laboratuvar teknikleri, 33 öğrencinin odyometri ve 48 öğrencinin optisyenlik bölümünde eğitim aldıkları tespit edilmiştir.

\subsection{Veri Toplama Araçları}

Araştırmaya ilişkin verilerin toplanmasında, öğrencilerin sosyal kaygılarını belirlemek amacıyla Özbay ve Palancı (2001) tarafindan geliştirilen "Sosyal Kaygı Ölçeği”; genel öz-yeterliklerini belirlemek içinse Sherer, Maddux, Mercandante, Dunn, Jacobs ve Rogers (1982) tarafından geliştirilen Türkçeye uyarlaması Yıldırım ve İlhan (2010) tarafından yapılan "Genel Öz-Yeterlik Ölçeği" kullanılmıştır.

\subsubsection{Sosyal Kaygı Ölçĕgi}

SHMYO'da öğrenim görmekte olan öğrencilerin sosyal kayg1 düzeylerinin belirlenmesi amacıyla Özbay ve Palancı (2001) tarafından geliştirilen "Sosyal Kaygı Ölçeği” kullanılmıştır. Ölçek toplamda 30 madde ve sosyal kaçınma (12 madde), kritize edilme kaygısı (10 madde) ve değersizlik 
duygusu (8 madde) olmak üzere üç alt boyuttan oluşmaktadır. Ölçeğin toplam güvenirliği .89; bu çalışmada ise sosyal kaçınma alt boyutu için .92, kritize edilme kaygısı alt boyutu için .85, değersizlik duygusu alt boyutu için .85 ve toplamda ise .94 olarak belirlenmiştir. Ölçek; "Hiçbir zaman=0", "Çok $a z=1$ ", "Ara sıra=2", "Slk $s l k=3$ " ve "Her zaman=4" şeklinde derecelendirilmiş beşli likert tipinde hazırlanmıştır. Ölçekten alınabilecek en düşük puan 0 , en yüksek puan ise 120 olmaktadır.

\subsubsection{Genel Öz-Yeterlik Ölçeği}

SHMYO'da öğrenim görmekte olan öğrencilerin genel öz-yeterliklerini belirlemek amaciyla Sherer, Maddux, Mercandante, Dunn, Jacobs ve Rogers (1982 tarafından geliştirilen Türkçeye uyarlaması Yıldırım ve İlhan (2010) tarafından yapılan "Genel Öz-yeterlik Ölçeği”" kullanılmıştır. Ölçek; başlama ( 9 madde), yılmama (5 madde) ve israr (3 madde) olmak üzere üç alt boyuttan ve toplamda 17 maddeden oluşmaktadır. Uyarlanan ölçeğin toplam güvenirliği .80 , bu çalışmada ise .86 olarak bulunmuştur. Ölçekteki sorular, sizi ne kadar tanımlıyor olarak ifade edilmiş ve "hiç=1" ve "çok iyi=5" arasında puanlanan orijinal beşli likert tipindeki şekliyle kullanılmıştır. Ölçekten alınabilecek en yüksek puan 85 , en düşük puan ise 17 olmaktadır.

\subsection{Verilerin Toplanması ve Analizi}

Araştırmaya ilişkin veriler, 2018-2019 eğitim-öğretim yılı bahar döneminde Sivas Cumhuriyet Üniversitesi SHMYO'da öğrenim görmekte olan öğrencilere ölçeklerin uygulanmasıyla elde edilmiştir. Ölçekler gerekli izinler alınarak ve öğrencilerin gönüllülügü dikkate alınarak uygulanmıştır. Ölçekler, toplamda 902 öğrenciye uygulanmış ancak ölçeklerin 31 tanesi analiz için gerekli özellikleri taşımadığı belirlendiği için araştırmaya dâhil edilmemiş, 871 ölçek değerlendirmeye alınarak analiz edilmiştir. Verilerin analizi SPSS 25.0 istatistik programı kullanılarak yapılmıştır. Puanların normal dağılıp dağılmadığını belirlemek amacıyla Kolmogorov-Smirnov (K-S) Testi uygulanmıştır. Verilerin normallik analizleri yapılarak aritmetik ortalama ve standart sapma puanları belirlenmiștir. Yapılan bu testlerde verilerin normallik değerlerini karşıladığı bulgusuna ulaşıldığı için bulgular öğrencilerin sosyal kaygılarının demografik değişkenlere göre anlamlı olarak farklılaşıp farklılaşmadığını belirlemek amacıyla ANOVA ve bağımsız gruplar T testi kullanılmışır. ANOVA testinin uygulandığı değişkenler arasındaki farklılaşmanın hangi gruplar arasında olduğunu belirlemek amacıyla LSD testi yapılmıştır.

\section{BULGULAR}

Araştırmanın bu bölümünde SHMYO öğrencilerine uygulanan ölçekler sonucunda elde edilen bulgulara yer verilmiştir. Bulgular araştırma sorularının sırasına uygun olarak düzenlenmiş ve her tablo ile ilgili açıklamalara tablonun altında yer verilmiştir.

Sosyal kaygı ölçeğinin alt boyutları ve toplam puanı, genel öz-yeterlik ölçeğinin alt boyutları ve toplam puanına ilişkin verilerin ortalamalarına ilişkin bilgiler Tablo 2'de sunulmuştur.

Tablo 2. Ölçeklere ilişkin betimsel istatistikler

\begin{tabular}{lcccrr}
\hline Ölçekler & N & En düşük puan & En yüksek puan & Ort. & \multicolumn{1}{c}{ SS } \\
\hline Kaçınma & 871 & 0 & 48 & 18.65 & 10.18 \\
Kritize edilme & 871 & 0 & 40 & 15.13 & 7.39 \\
Değersizlik & 871 & 0 & 30 & 9.13 & 6.37 \\
Toplam & 871 & 0 & 116 & 42.92 & 20.61 \\
\hline Başlama & 871 & 12 & 45 & 33.81 & 5.76 \\
Yılmama & 871 & 7 & 25 & 18.55 & 3.41 \\
Israr & 871 & 4 & 15 & 10.60 & 1.97 \\
Toplam & 871 & 32 & 85 & 62.96 & 9.50 \\
\hline
\end{tabular}


Ölçeklerden elde edilen puan ortalamalarına bakıldığında; öğrencilerin kaygılarının ölçeğin kaçınma (38.85), kritize edilme (37.83), değersizlik (30.43) alt boyutlarında ve toplamda (37.00) orta düzeyde; öz-yeterlik puanlarının başlama (75.13), yılmama (74.20), ısrar (70.67) alt boyutlarında ve toplamda (74.07) yüksek düzeyde olduğu görülmektedir.

SHMYO öğrencilerin cinsiyet değişkenine göre sosyal kaygı ve genel öz-yeterlik puanlarında anlamlı farklılık olup olmadığının belirlenmesi amacıyla yapılan bağımsız gruplar $\mathrm{t}$ testi sonuçlarına ilişkin bulgulara Tablo 3'te yer verilmiştir.

Tablo 3. SHMYO öğrencilerinin cinsiyet değişkenine göre sosyal kaygıları ve öz-yeterlik algıları t-testi bulguları

\begin{tabular}{|c|c|c|c|c|c|c|}
\hline & Cinsiyet & $\mathbf{N}$ & Ort. & SS & $\mathbf{t}$ & $\mathbf{p}$ \\
\hline \multirow{2}{*}{ Kaçınma } & $\mathrm{K}_{1 \mathrm{Z}}$ & 670 & 18.57 & 10.22 & \multirow{2}{*}{-.434} & \multirow{2}{*}{.67} \\
\hline & Erkek & 201 & 18.93 & 10.06 & & \\
\hline \multirow{2}{*}{ Kritize Edilme } & $\mathrm{K}_{1 \mathrm{Z}}$ & 670 & 15.05 & 7.30 & \multirow{2}{*}{-.615} & \multirow{2}{*}{.54} \\
\hline & Erkek & 201 & 15.42 & 7.67 & & \\
\hline \multirow{2}{*}{ Değersizlik } & $\mathrm{K}_{12}$ & 670 & 9.03 & 6.30 & \multirow{2}{*}{-.815} & \multirow{2}{*}{.42} \\
\hline & Erkek & 201 & 9.46 & 6.63 & & \\
\hline \multirow{2}{*}{ Toplam } & $\mathrm{K}_{1 Z}$ & 670 & 42.65 & 20.44 & \multirow{2}{*}{-.685} & \multirow{2}{*}{.49} \\
\hline & Erkek & 201 & 43.81 & 21.19 & & \\
\hline \multirow{2}{*}{ Başlama } & $\mathrm{K} 1 \mathrm{Z}$ & 670 & 33.86 & 5.72 & \multirow{2}{*}{.492} & \multirow{2}{*}{.62} \\
\hline & Erkek & 201 & 33.63 & 5.91 & & \\
\hline \multirow{2}{*}{ Yilmama } & $\mathrm{K}_{1 \mathrm{Z}}$ & 670 & 18.47 & 3.47 & \multirow{2}{*}{-1.238} & \multirow{2}{*}{.22} \\
\hline & Erkek & 201 & 18.80 & 3.22 & & \\
\hline \multirow{2}{*}{ Israr } & $\mathrm{K}_{1 \mathrm{Z}}$ & 670 & 10.54 & 1.99 & \multirow{2}{*}{-1.473} & \multirow{2}{*}{.14} \\
\hline & Erkek & 201 & 10.78 & 1.91 & & \\
\hline \multirow{2}{*}{ Toplam } & $\mathrm{K}_{1 \mathrm{Z}}$ & 670 & 62.89 & 9.54 & \multirow{2}{*}{-.426} & \multirow{2}{*}{.67} \\
\hline & Erkek & 201 & 63.21 & 9.38 & & \\
\hline
\end{tabular}

Tablo 3'teki verilere göre; SHMYO öğrencilerinin cinsiyet değişkeni açısından sosyal kaygı düzeyleri ve genel öz-yeterlik algılarına ilişkin puanlarının ölçeklerin toplam ve alt boyutlarına ilişkin puanlarda anlamlı farklılık göstermediği $(\mathrm{p}>.05)$ tespit edilmiştir.

SHMYO öğrencilerin gelir düzeyi değişkenine göre sosyal kaygı puanlarında anlamlı farklılık olup olmadığının belirlenmesi amacıyla yapılan ANOVA sonuçlarına ilişkin bulgulara Tablo 4'te sunulmuştur.

Tablo 4. SHMYO öğrencilerinin gelir düzeyi değişkenine göre sosyal kaygıları ANOVA testi bulguları

\begin{tabular}{|c|c|c|c|c|c|c|c|}
\hline & $\begin{array}{l}\text { Gelir } \\
\text { düzeyi }\end{array}$ & $\mathbf{N}$ & Ort. & SS & $\mathbf{F}$ & $\mathbf{p}$ & $\begin{array}{c}\text { Anlamlı Fark } \\
\text { LSD }\end{array}$ \\
\hline \multirow{4}{*}{ Kaçınma } & Çok iyi & 22 & 17.09 & 8.92 & \multirow{4}{*}{2.968} & \multirow{4}{*}{$.03 *$} & \multirow{4}{*}{ İyi-orta* } \\
\hline & İyi & 279 & 17.51 & 10.13 & & & \\
\hline & Orta & 533 & 19.46 & 10.15 & & & \\
\hline & Düşük & 37 & 16.65 & 10.89 & & & \\
\hline \multirow{4}{*}{ Kritize edilme } & Çok iyi & 22 & 15.55 & 7.95 & \multirow{4}{*}{3.943} & \multirow{4}{*}{$.01 *$} & \multirow{4}{*}{$\begin{array}{c}\text { İyi-orta* } \\
\text { İyi-düşük* }\end{array}$} \\
\hline & İyi & 279 & 13.91 & 7.20 & & & \\
\hline & Orta & 533 & 15.66 & 7.32 & & & \\
\hline & Düşük & 37 & 16.54 & 8.47 & & & \\
\hline \multirow{4}{*}{ Değersizlik } & Çok iyi & 22 & 8.00 & 6.56 & \multirow{4}{*}{7.125} & \multirow{4}{*}{$.00 *$} & \multirow{4}{*}{ İyi-orta* } \\
\hline & İyi & 279 & 7.76 & 6.00 & & & \\
\hline & Orta & 533 & 9.86 & 6.44 & & & \\
\hline & Düşük & 37 & 9.68 & 6.59 & & & \\
\hline \multirow{4}{*}{ Toplam } & Çok iyi & 22 & 40.64 & 20.51 & \multirow{4}{*}{5.001} & \multirow{4}{*}{$.00 *$} & \multirow{4}{*}{ İyi-orta* } \\
\hline & İyi & 279 & 39.18 & 20.10 & & & \\
\hline & Orta & 533 & 44.98 & 20.49 & & & \\
\hline & Düşük & 37 & 42.86 & 22.86 & & & \\
\hline
\end{tabular}

*p<.05 
Tablo 4 incelendiğinde; SHMYO öğrencilerinin sosyal kaygı düzeylerine ilişkin puan ortalamalarının ölçeğin toplam ve alt boyutlarında anlamlı şekilde farklılaştığı $(\mathrm{p}<.05)$ görülmektedir. Anlamlı farklılığın hangi gruplar arasında olduğunun belirlenmesi amacıyla yapılan LSD testi sonucuna göre ölçeğin kaçınma, değersizlik alt boyutlarında ve toplam puanda "İyi-Orta" grupları arasında iyi lehine; kritize edilme alt boyutunda "İyi-Orta" ve "İyi-Düşük" grupları arasında iyi lehine anlamlı farklılığın olduğu belirlenmiştir. Ölçeğin toplam puanına bakıldığında gelir düzeyi değişkeni açısından sosyal kaygısı en düşük olan grubun gelir düzeyini iyi olarak belirten; sosyal kaygısı en düşük grubun ise gelir düzeyini orta olarak ifade eden grubun olduğu görülmektedir.

SHMYO öğrencilerinin gelir düzeyi değişkenine göre genel öz-yeterlik algılarına ilişkin puanlarında anlamlı farklılık olup olmadığının belirlenmesi amacıyla yapılan ANOVA sonuçlarına ilişkin bulgular Tablo 5’te sunulmuştur.

Tablo 5. SHMYO öğrencilerinin gelir düzeyi değişkenine göre genel öz-yeterlik algıları ANOVA testi bulguları

\begin{tabular}{|c|c|c|c|c|c|c|c|}
\hline 8 & & $\mathbf{N}$ & Ort. & SS & $\mathbf{F}$ & $\mathbf{p}$ & $\begin{array}{c}\text { Anlamlı Fark } \\
\text { LSD }\end{array}$ \\
\hline \multirow{4}{*}{ Başlama } & Çok iyi & 22 & 30.86 & 7.71 & \multirow{4}{*}{2.000} & \multirow{4}{*}{$.04 *$} & \multirow{4}{*}{$\begin{array}{l}\text { Çok iyi-İyi* } \\
\text { Çok iyi-Orta* }\end{array}$} \\
\hline & İyi & 279 & 33.92 & 5.79 & & & \\
\hline & Orta & 533 & 33.88 & 5.61 & & & \\
\hline & Düşük & 37 & 33.65 & 6.21 & & & \\
\hline \multirow{4}{*}{ Y1lmama } & Çok iyi & 22 & 18.41 & 3.47 & \multirow{4}{*}{.596} & \multirow{4}{*}{.62} & \multirow{4}{*}{ Yok } \\
\hline & İyi & 279 & 18.77 & 3.36 & & & \\
\hline & Orta & 533 & 18.44 & 3.41 & & & \\
\hline & Düşük & 37 & 18.51 & 3.83 & & & \\
\hline \multirow{4}{*}{ Israr } & Çok iyi & 22 & 11.32 & 2.44 & \multirow{4}{*}{1.700} & \multirow{4}{*}{.17} & \multirow{4}{*}{ Yok } \\
\hline & İyi & 279 & 10.60 & 1.91 & & & \\
\hline & Orta & 533 & 10.54 & 1.98 & & & \\
\hline & Düşük & 37 & 11.03 & 1.95 & & & \\
\hline \multirow{4}{*}{ Toplam } & Çok iyi & 22 & 60.59 & 12.48 & \multirow{4}{*}{.594} & \multirow{4}{*}{.62} & \multirow{4}{*}{ Yok } \\
\hline & İyi & 279 & 63.29 & 9.31 & & & \\
\hline & Orta & 533 & 62.87 & 9.40 & & & \\
\hline & Düşük & 37 & 63.19 & 10.40 & & & \\
\hline
\end{tabular}

Tablo 5'teki veriler incelendiğinde; SHMYO öğrencilerinin genel öz-yeterlik düzeylerine ilişkin puan ortalamalarının ölçeğin başlama alt boyutunda anlamlı şekilde farklılaştığı $(p<.05)$; diğer alt boyutlar ve toplam puanda ise anlamlı farklılık bulunmadığ 1 ( $>.05)$ görülmektedir. Anlamlı farklılığın hangi gruplar arasında olduğunun belirlenmesi amacıyla yapılan LSD analiz sonucuna göre farklılığın "Çok iyi-İyi" ve "Çok iyi-Orta" grupları arasında çok iyi grubu aleyhine olduğu saptanmıştır. Ölçeğin toplam puanına bakıldığında gelir düzeyi değişkeni açısından genel öz-yeterlik algısı en yüksek olan grubun iyi, en düşük grubun ise çok iyi olduğu görülmektedir.

SHMYO'da öğrenim görmekte olan öğrencilerin ikamet yeri değişkenine göre sosyal kayg1 puanlarında anlamlı farklılık olup olmadığının belirlenmesi amacıyla yapılan ANOVA testi sonuçlarına ilişkin verilere Tablo 6'da yer verilmektedir.

Tablo 6. SHMYO öğrencilerinin ikamet yeri değişkenine göre sosyal kaygı ANOVA testi bulguları

\begin{tabular}{llcccccc}
\hline & İkamet & N & Ort. & ss & F & p & Anlamlı Fark LSD \\
\hline \multirow{4}{*}{ Kaçınma } & Köy & 152 & 20.73 & 11.08 & & & \\
& İlçe & 191 & 19.06 & 9.95 & & & Köy-Şehir* \\
& Şehir & 409 & 18.15 & 10.05 & 3.536 & $.01^{*}$ & Köy-Büyükşehir* \\
& Büyükşehir & 119 & 17.08 & 9.43 & & & \\
\hline \multirow{2}{*}{ Kritize etme } & Köy & 152 & 16.95 & 7.90 & \multirow{2}{*}{4.918} & \multirow{2}{*}{$.00^{*}$} & $\begin{array}{c}\text { Köy-Şehir* } \\
\text { Köy-Büyükşehir* }\end{array}$ \\
\hline
\end{tabular}




\begin{tabular}{|c|c|c|c|c|c|c|c|}
\hline & Şehir & 409 & 14.46 & 7.38 & & & \\
\hline & Büyükșehir & 119 & 14.39 & 6.72 & & & \\
\hline \multirow{4}{*}{ Değersizlik } & Köy & 152 & 10.96 & 7.20 & \multirow{4}{*}{5.422} & \multirow{4}{*}{$.00^{*}$} & \multirow{4}{*}{$\begin{array}{c}\text { Köy-İlçe* } \\
\text { Köy-Şehir* } \\
\text { Köy-Büyükşehir* }\end{array}$} \\
\hline & İlçe & 191 & 8.97 & 5.90 & & & \\
\hline & Şehir & 409 & 8.77 & 6.34 & & & \\
\hline & Büyükşehir & 119 & 8.29 & 5.72 & & & \\
\hline \multirow{4}{*}{ Toplam } & Köy & 152 & 48.64 & 22.80 & \multirow{4}{*}{5.775} & \multirow{4}{*}{$.00^{*}$} & \multirow{4}{*}{$\begin{array}{c}\text { Köy-İlçe* } \\
\text { Köy-Şehir* } \\
\text { Köy-Büyükşehir* }\end{array}$} \\
\hline & İlçe & 191 & 43.63 & 19.37 & & & \\
\hline & Şehir & 409 & 41.38 & 20.60 & & & \\
\hline & Büyükșehir & 119 & 39.75 & 18.29 & & & \\
\hline
\end{tabular}

Tablo 6'daki veriler incelendiğinde; SHMYO öğrencilerinin ikamet yeri değişkenine göre sosyal kaygılarının tüm alt boyut ve toplam puan ortalamalarına göre anlamlı farklılık gösterdiği $(\mathrm{p}<.05)$ tespit edilmiştir. Anlamlı farklılığın belirlenmesi amacıyla yapılan LSD testi sonuçlarına göre kaçınma ve kritize etme alt boyutlarında "Köy-Şehir" ve "Köy-Büyükşehir" grupları arasında köy aleyhine; 1srar alt boyutu ve toplam puanda "Köy-İlçe”, "Köy-Şehir" ve "Köy-Büyükşehir" grupları arasında köy aleyhine farklılık bulunduğu saptanmıştır. Toplam puan açısından bakıldığında en düşük sosyal kaygı puanına büyükşehirde yaşayan öğrencilerin en düşük kaygı puanına ise köyde yaşayan öğrencilerin sahip oldukları görülmektedir. Öğrencilerin sosyal kaygılarının ikamet ettikleri yer bağlamında nüfusu kalabalık olan yerleşim alanlarından nüfusu az olan yerleşim alanlarına doğru yapılan sıralamaya göre artış gösterdiği görülmektedir.

SHMYO öğrencilerin ikamet yeri değişkenine göre genel öz-yeterlik algılarına ilişkin puanlarında anlamlı farklılık olup olmadığının belirlenmesi amacıyla yapılan ANOVA testi sonuçlarına ilişkin verilere Tablo 7'de yer verilmektedir.

Tablo 7. SHMYO öğrencilerinin ikamet yeri değişkenine göre genel öz-yeterlik algıları ANOVA testi bulguları

\begin{tabular}{|c|c|c|c|c|c|c|c|}
\hline & $\begin{array}{l}\text { İkamet } \\
\text { Yeri }\end{array}$ & $\mathbf{N}$ & Ort. & SS & $\mathbf{F}$ & $\mathbf{p}$ & $\begin{array}{c}\text { Anlamlı Fark } \\
\text { LSD }\end{array}$ \\
\hline \multirow{4}{*}{ Başlama } & Köy & 152 & 34.08 & 5.60 & \multirow{4}{*}{1.160} & \multirow{4}{*}{.32} & \multirow{4}{*}{ Yok } \\
\hline & İlçe & 191 & 33.83 & 5.23 & & & \\
\hline & Şehir & 409 & 33.49 & 5.97 & & & \\
\hline & Büyükşehir & 119 & 34.54 & 6.03 & & & \\
\hline \multirow{4}{*}{ Yilmama } & Köy & 152 & 18.46 & 3.26 & \multirow{4}{*}{.226} & \multirow{4}{*}{.88} & \multirow{4}{*}{ Yok } \\
\hline & İlçe & 191 & 18.67 & 3.24 & & & \\
\hline & Şehir & 409 & 18.49 & 3.53 & & & \\
\hline & Büyükşehir & 119 & 18.69 & 3.50 & & & \\
\hline \multirow{4}{*}{ Israr } & Köy & 152 & 10.76 & 1.81 & \multirow{4}{*}{.737} & \multirow{4}{*}{.53} & \multirow{4}{*}{ Yok } \\
\hline & İlçe & 191 & 10.50 & 1.85 & & & \\
\hline & Şehir & 409 & 10.55 & 2.08 & & & \\
\hline & Büyükşehir & 119 & 10.73 & 2.00 & & & \\
\hline \multirow{4}{*}{ Toplam } & Köy & 152 & 63.30 & 8.82 & \multirow{4}{*}{.784} & \multirow{4}{*}{.50} & \multirow{4}{*}{ Yok } \\
\hline & İlçe & 191 & 63.00 & 8.77 & & & \\
\hline & Şehir & 409 & 62.53 & 9.93 & & & \\
\hline & Büyükşehir & 119 & 63.96 & 9.94 & & & \\
\hline
\end{tabular}

Tablo 7'de yer alan bulgulara bakıldığında SHMYO'da öğrencilerin genel öz-yeterlik algılarının ikamet yeri değişkeni açısından ölçeğin alt boyutları ve toplam puan ortalamalarında anlamlı farklılık ( $>$ >.05) oluşturmadığı görülmektedir. Toplam puan açısından öğrencilerin genel özyeterlik algı düzeylerinin en yüksek büyükşehirde en düşük ise şehirde yaşayan öğrencilerde bulunduğu tespit edilmiştir. 
SHMYO öğrencilerin mezun oldukları lise türü değişkenine göre sosyal kaygı puan ortalamalarında anlamlı farklılık olup olmadı̆̆ının belirlenmesi amacıyla yapılan ANOVA testi sonuçlarına ilişkin veriler Tablo 8'de sunulmaktadır.

Tablo 8. SHMYO öğrencilerinin mezun oldukları lise türü değişkenine göre sosyal kaygı ANOVA testi bulguları

\begin{tabular}{|c|c|c|c|c|c|c|c|}
\hline & İkamet Yeri & $\mathbf{N}$ & Ort. & SS & $\mathbf{F}$ & $\mathbf{p}$ & Anlamlı Fark LSD \\
\hline \multirow{5}{*}{ Kaçınma } & Genel lise & 146 & 17.59 & 9.94 & \multirow{5}{*}{1.136} & \multirow{5}{*}{$.04^{*}$} & \multirow{5}{*}{ Genel-İmam hatip* } \\
\hline & İmam hatip lisesi & 73 & 20.60 & 9.65 & & & \\
\hline & Mesleki teknik lise & 179 & 18.55 & 11.18 & & & \\
\hline & Sağlık meslek lisesi & 231 & 18.49 & 9.59 & & & \\
\hline & Anadolu lisesi & 242 & 18.94 & 10.25 & & & \\
\hline \multirow{5}{*}{$\begin{array}{l}\text { Kritize } \\
\text { edilme }\end{array}$} & Genel lise & 146 & 14.30 & 7.22 & \multirow{5}{*}{1.627} & \multirow{5}{*}{$.04^{*}$} & \multirow{5}{*}{$\begin{array}{l}\text { Anadolu-Genel* } \\
\text { Anadolu-Sağlık* }\end{array}$} \\
\hline & İmam hatip lisesi & 73 & 15.01 & 6.82 & & & \\
\hline & Mesleki teknik lise & 179 & 15.24 & 8.23 & & & \\
\hline & Sağlık meslek lisesi & 231 & 14.67 & 6.58 & & & \\
\hline & Anadolu lisesi & 242 & 16.04 & 7.67 & & & \\
\hline \multirow{5}{*}{ Değersizlik } & Genel lise & 146 & 8.74 & 6.38 & \multirow{5}{*}{.963} & \multirow{5}{*}{.43} & \multirow{5}{*}{ Yok } \\
\hline & İmam hatip lisesi & 73 & 9.67 & 5.16 & & & \\
\hline & Mesleki teknik lise & 179 & 8.98 & 6.45 & & & \\
\hline & Sağlık meslek lisesi & 231 & 8.74 & 6.19 & & & \\
\hline & Anadolu lisesi & 242 & 9.69 & 6.80 & & & \\
\hline \multirow{5}{*}{ Toplam } & Genel lise & 146 & 40.63 & 20.21 & \multirow{5}{*}{1.271} & \multirow{5}{*}{.28} & \multirow{5}{*}{ Yok } \\
\hline & İmam hatip lisesi & 73 & 45.29 & 18.64 & & & \\
\hline & Mesleki teknik lise & 179 & 42.77 & 22.73 & & & \\
\hline & Sağlık meslek lisesi & 231 & 41.90 & 18.47 & & & \\
\hline & Anadolu lisesi & 242 & 44.67 & 21.63 & & & \\
\hline
\end{tabular}

Tablo 8'deki bulgular analiz edildiğinde; öğrencilerin mezun olunan okul türü değişkenine göre ölçeğin kaçınma ve kritize edilme alt boyutlarında anlamlı farklılık $(p<.05)$ olduğu, değersizlik alt boyutu ve toplam puanda ise anlamlı farklılık olmadığı (p>.05) tespit edilmiştir. Farklılığın kaçınma alt boyutunda "Genel Lise-Imam Hatip Lisesi" arasinda genel lise lehine; "Anadolu Lisesi-Genel Lise" ve "Anadolu Lisesi-Sağlık Meslek Lisesi" arasında Anadolu lisesi aleyhine olduğu belirlenmiştir. Toplam puan açısından öğrencilerin sosyal kaygı puan ortalamalarına bakıldığında en yüksek kaygı puan ortalamasına imam hatip lisesi mezunu öğrencilerin, en düşük kaygı puan ortalamasına ise genel lise mezunu öğrencilerin sahip oldukları olduğu görülmektedir.

SHMYO öğrencilerinin mezun oldukları okul türü değişkenine göre genel öz-yeterlik algılarına ilişkin puan ortalamalarında anlamlı farklılık olup olmadığının belirlenmesi amacıyla yapılan ANOVA testi sonuçlarına ilişkin veriler Tablo 9'da yer almaktadır.

Tablo 9. SHMYO öğrencilerinin mezun oldukları lise türü değişkenine göre genel öz-yeterlik algıları ANOVA testi bulguları

\begin{tabular}{|c|c|c|c|c|c|c|c|}
\hline & İkamet Yeri & $\mathbf{N}$ & Ort. & SS & $\mathbf{F}$ & p & Anlamlı Fark LSD \\
\hline \multirow{5}{*}{ Başlama } & Genel lise & 146 & 33.54 & 5.42 & \multirow{5}{*}{.582} & \multirow{5}{*}{.28} & \multirow{5}{*}{ Yok } \\
\hline & İmam hatip lisesi & 73 & 34.03 & 5.39 & & & \\
\hline & Mesleki teknik lise & 179 & 33.65 & 6.02 & & & \\
\hline & Sağlık meslek lisesi & 231 & 34.26 & 5.86 & & & \\
\hline & Anadolu lisesi & 242 & 33.60 & 5.81 & & & \\
\hline \multirow{5}{*}{ Yilmama } & Genel lise & 146 & 18.10 & 3.33 & \multirow{5}{*}{2.047} & \multirow{5}{*}{$.04^{*}$} & \multirow{5}{*}{$\begin{array}{c}\text { Sağlık-Genel* } \\
\text { Sağlık-Anadolu* }\end{array}$} \\
\hline & İmam hatip lisesi & 73 & 18.30 & 3.54 & & & \\
\hline & Mesleki teknik lise & 179 & 18.70 & 3.45 & & & \\
\hline & Sağlık meslek lisesi & 231 & 19.00 & 3.52 & & & \\
\hline & Anadolu lisesi & 242 & 18.35 & 3.26 & & & \\
\hline Israr & Genel lise & 146 & 10.61 & 1.91 & .232 & .09 & Yok \\
\hline
\end{tabular}




\begin{tabular}{llrrrrrr}
\hline & İmam hatip lisesi & 73 & 10.55 & 1.94 & & \\
& Mesleki teknik lise & 179 & 10.69 & 1.96 & & \\
& Sağlık meslek lisesi & 231 & 10.63 & 2.03 & & \\
& Anadolu lisesi & 242 & 10.52 & 1.98 & & \\
\hline \multirow{4}{*}{ Toplam } & Genel lise & 146 & 62.25 & 8.99 & & & \\
& İmam hatip lisesi & 73 & 62.88 & 9.48 & & & \\
& Mesleki teknik lise & 179 & 63.04 & 9.69 & .933 & .44 & \\
& Sağlık meslek lisesi & 231 & 63.90 & 9.95 & & & \\
& Anadolu lisesi & 242 & 62.46 & 9.21 & & \\
\hline
\end{tabular}

Tablo 9'da yer alan bulgulara göre; öğrencilerin genel öz-yeterlik düzeylerinin mezun oldukları lise türü açısından ölçeğin yılmama alt boyutunda "Sağllk Meslek Lisesi-Genel Lise" ve "Sağglk Meslek Lisesi-Anadolu Lisesi” arasında sağlık lisesi lehine anlamlı farklılık $(\mathrm{p}<.05)$ gösterdiği, diğer alt boyutlar ve toplam puanda ise anlamlı farklılık göstermediği ( $>$ >.05) belirlenmiştir. Toplam puan açısından değerlendirildiğinde sağlik meslek lisesi öğrencilerinin genel öz-yeterlik algısı en yüksek olan grup, genel liseden mezun olan öğrencilerin ise öz-yeterlik algısı en düşük olan grup olduğu saptanmıştır.

SHMYO öğrencilerin branş değişkenine göre sosyal kaygı puanlarında anlamlı farklılık olup olmadığının belirlenmesi amacıyla yapılan ANOVA testi sonuçlarına ilişkin veriler Tablo 10 'da yer almaktadır.

Tablo 10. SHMYO öğrencilerinin branş değişkenine göre sosyal kaygı ANOVA testi bulguları

\begin{tabular}{|c|c|c|c|c|c|c|c|}
\hline & İkamet Yeri & $\mathbf{N}$ & Ort. & SS & $\mathbf{F}$ & p & Anlamlı Fark LSD \\
\hline \multirow{10}{*}{ Kaçınma } & Fizyoterapi & 90 & 18.44 & 9.75 & \multirow{10}{*}{2.054} & \multirow{10}{*}{$.02 *$} & \multirow{10}{*}{$\begin{array}{c}\text { Tıbbi dok.- Eczane Hiz* } \\
\text { Çocuk gel.-Eczane Hiz.* } \\
\text { Görüntüleme tek.-Eczane Hiz.* } \\
\text { Yaşlı bak. -Eczane Hiz.* } \\
\text { Yaşlı bak.- İlk ve acil yar.* } \\
\text { Yaşlı bak.-Optisyenlik* }\end{array}$} \\
\hline & Tibbi dok. ve sek. & 102 & 18.94 & 10.63 & & & \\
\hline & Çocuk gelişimi & 210 & 18.80 & 10.74 & & & \\
\hline & Tibbi gör. tek. & 52 & 19.46 & 8.31 & & & \\
\hline & Yaşlı bakımı & 162 & 20.47 & 10.50 & & & \\
\hline & İlk ve acil yardim & 104 & 16.65 & 8.34 & & & \\
\hline & Eczane hizmetleri & 27 & 14.52 & 8.24 & & & \\
\hline & Tibbi lab. tek. & 43 & 19.16 & 11.43 & & & \\
\hline & Odyometri & 33 & 19.39 & 11.88 & & & \\
\hline & Optisyenlik & 48 & 15.75 & 9.35 & & & \\
\hline \multirow{10}{*}{$\begin{array}{l}\text { Kritize } \\
\text { edilme }\end{array}$} & Fizyoterapi & 90 & 15.38 & 7.74 & \multirow{10}{*}{1.167} & \multirow{10}{*}{$.04 *$} & \multirow{10}{*}{$\begin{array}{l}\text { T1bbi dok.-İlk ve acil yar.* } \\
\text { Yaşlı bak.- İlk ve acil yar.* }\end{array}$} \\
\hline & Tibbi dok. ve sek. & 102 & 15.88 & 7.86 & & & \\
\hline & Çocuk gelişimi & 210 & 15.09 & 7.48 & & & \\
\hline & T1bbi gör. tek. & 52 & 15.19 & 6.15 & & & \\
\hline & Yaşlı bakımı & 162 & 15.95 & 7.22 & & & \\
\hline & İlk ve acil yardım & 104 & 13.50 & 6.34 & & & \\
\hline & Eczane hizmetleri & 27 & 13.93 & 6.11 & & & \\
\hline & Tibbi lab. tek. & 43 & 15.53 & 9.58 & & & \\
\hline & Odyometri & 33 & 15.70 & 7.58 & & & \\
\hline & Optisyenlik & 48 & 13.96 & 7.27 & & & \\
\hline \multirow{10}{*}{ Değersizlik } & Fizyoterapi & 90 & 9.51 & 7.39 & & & \multirow{10}{*}{$\begin{array}{l}\text { Tibbi dok.-İlk ve acil yar.* } \\
\text { Tibbi dok.-Eczane Hiz.* } \\
\text { İlk ve acil yar.-Odyometri* } \\
\text { Eczane Hiz.-Odyometri* }\end{array}$} \\
\hline & Tibbi dok. ve sek. & 102 & 10.10 & 6.31 & & & \\
\hline & Çocuk gelişimi & 210 & 9.10 & 6.08 & & & \\
\hline & Tibbi gör. tek. & 52 & 9.50 & 5.89 & & & \\
\hline & Yaşlı bakımı & 162 & 9.04 & 6.15 & & & \\
\hline & Illk ve acil yardim & 104 & 7.73 & 5.43 & 1.685 & .08 & \\
\hline & Eczane hizmetleri & 27 & 7.03 & 4.75 & & & \\
\hline & Tibbi lab. tek. & 43 & 9.30 & 7.61 & & & \\
\hline & Odyometri & 33 & 11.39 & 7.13 & & & \\
\hline & Optisyenlik & 48 & 8.92 & 7.43 & & & \\
\hline Toplam & Fizyoterapi & 90 & 43.73 & 22.17 & 1.867 & .5 & Fizyoterapi- İlk ve acil yar.* \\
\hline
\end{tabular}




\begin{tabular}{lrrrc}
\hline Tibbi dok. ve sek. & 102 & 44.92 & 21.89 & Tibbi dok.- İlk ve acil yar.* $^{*}$ \\
Çocuk gelişimi & 210 & 42.99 & 20.99 & Çocuk gel.- İlk ve acil yar.* \\
Tibbi gör. tek. & 52 & 44.15 & 17.05 & Yaşlı bak.- İlk ve acil yar.* \\
Yaşlı bakımı & 162 & 45.46 & 19.66 & Odyometri-İlk ve acil yar.* \\
İlk ve acil yardım & 104 & 37.88 & 17.07 & Tibbi dok.-Eczane Hiz.* \\
Eczane hizmetleri & 27 & 35.48 & 14.86 & Yaşl bak.- Eczane Hiz.* \\
Tibbi lab. tek. & 43 & 44.00 & 25.67 & Odyometri- Eczane Hiz.* \\
Odyometri & 33 & 46.48 & 24.03 & Yaşlı bak.-Optisyenlik* \\
Optisyenlik & 48 & 38.63 & 20.30 & \\
\hline
\end{tabular}

Tablo 10'da yer alan veriler analiz edildiğinde; SHMYO'da öğrenim görmekte olan öğrencilerin branş değişkeni açısından sosyal kaygı puanlarının ölçeğin tüm alt boyutlarında ve toplam puanında anlamlı farklılık $(\mathrm{p}<.05)$ oluşturduğu belirlenmiştir. Anlamlı farklılığın olduğu grupların belirlenmesi amacıyla yapılan LSD testinden elde edilen bulgulara göre ölçeğin kaçınma alt boyutunda "Tıbbi Dokümantasyon ve Sekreterlik-Eczane Hizmetleri", "Çocuk Gelişimi-Eczane Hizmetleri”, "Tibbi Görüntüleme Teknikleri-Eczane Hizmetleri”, "Yaşlı Bakımı-Eczane Hizmetleri" arasında eczane hizmetleri lehine, "Yaşlı Bakımı-İlk ve Acil Yardım" ve "Yaşlı Bakımı-Optisyenlik" arasında yaşlı bakımı aleyhine; kritize edilme alt boyutunda "Tibbi Dokümantasyon ve Sekreterlik-Ilk ve Acil Yardım" ve "Yaşlı Bakımı-İlk ve Acil Yardım" arasında ilk ve acil yardım lehine; değersizlik alt boyutunda "Tlbbi Dokümantasyon ve Sekreterlik-Ilk ve Acil Yardım", "Tlbbi Dokümantasyon ve Sekreterlik-Eczane Hizmetleri" arasında tıbbi dokümantasyon ve sekreterlik aleyhine, "Illk ve Acil Yardım-Odyometri", "Eczane Hizmetleri-Odyometri" arasında odyometri aleyhine; toplam puanda ise "Fizyoterapi-İlk ve Acil Yardım", "Tıbbi Dokümantasyon ve Sekreterlik-IIlk ve Acil Yardım”, "Çocuk Gelişimi-Illk ve Acil Yardım", "Yaşlı Bakımı-İlk ve Acil Yardım”, "Odyometri-İlk ve Acil Yardım" arasında ilk ve acil yardım lehine, "Tıbbi Dokümantasyon ve Sekreterlik-Eczane Hizmetleri", "Yaşlı Bakımı-Eczane Hizmetleri", "Odyometri-Eczane Hizmetleri" arasında eczane hizmetleri lehine, "Yaşlı Bakımı-Optisyenlik" arasında optisyenlik lehine anlamlı farklılığın olduğu saptanmıştır. Toplam puan açısından bakıldığında; en yüksek sosyal kaygı puanına odyometri bölümünde öğrenim gören öğrencilerin en düşük sosyal kaygı puanına ise eczane hizmetleri bölümünde eğitim gören öğrencilerin sahip oldukları görülmektedir.

SHMYO öğrencilerin branş değişkenine göre genel öz-yeterlik algılarına ilişkin puanlarında anlamlı farklılık olup olmadığının belirlenmesi amacıyla yapılan ANOVA testi sonuçlarına ilişkin verilere Tablo 11'de yer verilmektedir.

Tablo 11. SHMYO öğrencilerinin branş değişkenine göre genel öz-yeterlik algıları ANOVA testi bulguları

\begin{tabular}{|c|c|c|c|c|c|c|c|}
\hline & İkamet Yeri & $\mathbf{N}$ & Ort. & SS & $\mathbf{F}$ & $\mathbf{p}$ & Anlamlı Fark LSD \\
\hline \multirow{11}{*}{ Başlama } & Fizyoterapi & 90 & 35.12 & 5.47 & \multirow{11}{*}{3.199} & \multirow{11}{*}{$.00 *$} & Fizyoterapi-Tibbi dok.* \\
\hline & Tıbbi dok. ve sek. & 102 & 33.17 & 5.99 & & & Fizyoterapi-Tıbbi gör.* \\
\hline & Çocuk gelişimi & 210 & 34.50 & 5.10 & & & Fizyoterapi-Yaşlı bak.* \\
\hline & Tibbi gör. tek. & 52 & 32.44 & 5.11 & & & Fizyoterapi-Odyometri* \\
\hline & Yasli bakımı & 162 & 32.66 & 6.39 & & & İlk ve acil yar.-Tibbi dok.* \\
\hline & İlk ve acil vardım & 104 & 3505 & 537 & & & $\begin{array}{l}\text { llk ve acil yar.-T1bbi gor.* } \\
\text { Illk ve acil var.-Yaslı bak.* }\end{array}$ \\
\hline & Fcrane hizmetleri & 107 & 32.00 & 6.15 & & & İlk ve acil yar.-Odyometri* \\
\hline & Eczane hızmetlerı & 21 & 33.56 & 0.15 & & & Çocuk gel.-Yaşlı bak.* \\
\hline & T1bbi lab. tek. & 43 & 34.51 & 4.85 & & & Çocuk gel.-Odyometri* \\
\hline & Odyometri & 33 & 31.85 & 5.88 & & & Çocuk gel.-Tibbi gör.* \\
\hline & Optisyenlik & 48 & 33.23 & 7.00 & & & Tibbi lab.-Odyometri* \\
\hline \multirow{6}{*}{ Y1lmama } & Fizyoterapi & 90 & 19.00 & 3.49 & \multirow{6}{*}{1.773} & \multirow{6}{*}{$.03 *$} & Fizyoterapi-Tıbbi gör.* \\
\hline & T1bbi dok. ve sek. & 102 & 18.13 & 3.26 & & & Eczane Hiz.-Tıbbi gör.* \\
\hline & Çocuk gelişimi & 210 & 18.58 & 3.41 & & & İlk ve acil yar.-Tibbi dok.* \\
\hline & Tibbi gör. tek. & 52 & 17.56 & 3.10 & & & İlk ve acil yar.-Tıbbi gör.* \\
\hline & Yaşlı bakımı & 162 & 17.37 & 3.51 & & & $\begin{array}{l}\text { 11k ve acil yar.-Yaşl1 bak.* } \\
\text { İlk ve acil yar.-Odyometri* }\end{array}$ \\
\hline & İlk ve acil yardım & 104 & 19.26 & 3.27 & & & \\
\hline
\end{tabular}




\begin{tabular}{|c|c|c|c|c|c|c|c|}
\hline & Eczane hizmetleri & 27 & 19.33 & 3.49 & & & \\
\hline & Tibbi lab. tek. & 43 & 18.81 & 3.51 & & & \\
\hline & Odyometri & 33 & 17.79 & 3.19 & & & \\
\hline & Optisyenlik & 48 & 18.48 & 3.64 & & & \\
\hline \multirow{10}{*}{ Israr } & Fizyoterapi & 90 & 11.00 & 1.81 & \multirow{10}{*}{1.316} & \multirow{10}{*}{$.04 *$} & \multirow{10}{*}{$\begin{array}{c}\text { Fizyoterapi-Tıbbi dok.* } \\
\text { Fizyoterapi-Tıbbi gör.* } \\
\text { Fizyoterapi-Yaşlı bak.* } \\
\text { Fizyoterapi-Eczane Hiz.* }\end{array}$} \\
\hline & Tibbi dok. ve sek. & 102 & 10.36 & 1.86 & & & \\
\hline & Çocuk gelişimi & 210 & 10.74 & 1.92 & & & \\
\hline & T1bbi gör. tek. & 52 & 10.29 & 2.02 & & & \\
\hline & Yaşlı bakımı & 162 & 10.40 & 2.03 & & & \\
\hline & İlk ve acil yardım & 104 & 10.79 & 1.92 & & & \\
\hline & Eczane hizmetleri & 27 & 10.11 & 1.99 & & & \\
\hline & Tibbi lab. tek. & 43 & 10.60 & 2.66 & & & \\
\hline & Odyometri & 33 & 10.58 & 1.82 & & & \\
\hline & Optisyenlik & 48 & 10.65 & 1.90 & & & \\
\hline \multirow{10}{*}{ Toplam } & Fizyoterapi & 90 & 65.12 & 9.45 & \multirow{10}{*}{2.864} & \multirow{10}{*}{$.00^{*}$} & \multirow{10}{*}{$\begin{array}{c}\text { Fizyoterapi-Tibbi dok.* } \\
\text { Fizyoterapi-Tıbbi gör.* } \\
\text { Fizyoterapi-Yaşlı bak.* } \\
\text { Fizyoterapi-Odyometri* } \\
\text { İlk ve acil yar.-Tıbbi dok.** } \\
\text { İlk ve acil yar.-Tıbbi gör.* } \\
\text { İlk ve acil yar.-Yaşlı bak.* } \\
\text { İlk ve acil yar.-Odyometri* } \\
\text { Çocuk gel.-Yaşlı bak.* } \\
\text { Çocuk gel.-Odyometri* } \\
\text { Çocuk gel.-Tibbi gör.* }\end{array}$} \\
\hline & Tibbi dok. ve sek. & 102 & 61.66 & 9.72 & & & \\
\hline & Çocuk gelişimi & 210 & 63.82 & 8.84 & & & \\
\hline & Tibbi gör. tek. & 52 & 60.29 & 8.97 & & & \\
\hline & Yaşlı bakımı & 162 & 61.43 & 9.78 & & & \\
\hline & İlk ve acil yardım & 104 & 65.10 & 9.24 & & & \\
\hline & Eczane hizmetleri & 27 & 63.00 & 9.88 & & & \\
\hline & Tibbi lab. tek. & 43 & 63.93 & 8.93 & & & \\
\hline & Odyometri & 33 & 60.21 & 9.56 & & & \\
\hline & Optisyenlik & 48 & 62.35 & 10.52 & & & \\
\hline
\end{tabular}

Tablo 11 incelendiğinde; SHMYO öğrencilerinin branş değişkenine göre genel öz-yeterlik algılarına ilişkin puanlarının ölçeğin tüm alt boyutlarında ve toplam puanda anlamlı farklılık $(\mathrm{p}<.05)$ gösterdiği belirlenmiştir. Anlamlı farklılığın ölçeğin başlama alt boyutunda ve toplam puanına "Fizyoterapi-Tıbbi Dokümantasyon ve Sekreterlik", "Fizyoterapi-Tıbbi Görüntüleme Teknikleri", "Fizyoterapi-Yaşlı Bakımı", "Fizyoterapi-Odyometri", "Fizyoterapi-Optisyenlik" arasında fizyoterapi lehine; "Illk ve Acil Yardım-Tıbbi Görüntüleme Teknikleri”, "Illk ve Acil Yardım-Yaşlı Bakımı”, "Illk ve Acil Yardım-Tibbi Dokümantasyon ve Sekreterlik", "Illk ve Acil Yardım-Odyometri" arasında ilk ve acil yardım lehine; "Çocuk Gelişimi-Yaşlı Bakımı", "Çocuk Gelişimi-Odyometri”, "Çocuk GelişimiTıbbi Görüntüleme Teknikleri” arasında çocuk gelişimi lehine olduğu görülmektedir. Ölçeğin y1lmama alt boyutunda "Fizyoterapi-Tıbbi Görüntüleme Teknikleri", "Eczane Hizmetleri- Tibbi Görüntüleme Teknikleri" arasında tıbbi görüntüleme teknikleri aleyhine; "Illk ve acil yardım-Tıbbi Dokümantasyon ve Sekreterlik", "Illk ve acil yardım-Yaşlı Bakımı", "Illk ve acil yardım-Odyometri", arasında ilk ve acil yardım lehine; israr alt boyutunda "Fizyoterapi-Tibbi Dokümantasyon ve Sekreterlik", "Fizyoterapi-Tibbi Görüntüleme Teknikleri", "Fizyoterapi-Yaşlı Bakımı", "FizyoterapiEczane Hizmetleri” "arasında fizyoterapi lehine anlamlı farklılı̆̆ın olduğu tespit edilmiştir. Ölçekten alınan toplam puana göre en yüksek puanı fizyoterapi öğrencilerinin en düşük puanı ise odyometri öğrencilerinin aldığı görülmektedir.

SHMYO öğrencilerin sosyal kaygı düzeyleri ile genel öz-yeterlik algılarının alt boyutlar ve toplam puana göre aralarındaki korelasyon düzeyinin belirlenmesi amacıyla yapılan Pearson Korelasyon testi sonuçları Tablo 12'de sunulmuştur.

Tablo 14. SHMYO öğrencilerinin sosyal kaygı ve öz-yeterlik algıları arasındaki korelasyon testi sonuçları

\begin{tabular}{lcccccccc}
\hline & Kaçın. & Kritize e. & Değersiz. & S. K. Top. & Başlama & Yılmama & Israr & Öz. Top. \\
\hline Kaçınma & 1.00 & $.59^{*}$ & $.58^{*}$ & $.89^{*}$ & $-.32^{*}$ & $-.33^{*}$ & -.15 & $-.34^{*}$ \\
Kritize e. & & 1.00 & $.68^{*}$ & $.86^{*}$ & $-.31^{*}$ & -.28 & -.18 & $-.31^{*}$ \\
Değersizlik & & & 1.00 & $.83^{*}$ & $-.42^{*}$ & $-.43^{*}$ & -.18 & $-.45^{*}$ \\
S. K. Top. & & & & 1.00 & $-.40^{*}$ & $-.40^{*}$ & -.16 & $-.42^{*}$ \\
Başlama. & & & & & 1.00 & $.67^{*}$ & $.43^{*}$ & $.94^{*}$
\end{tabular}


Tablo 12'deki korelasyon sonuçları incelendiğinde; sosyal kayg1 ölçeğinin kaçınma alt boyutunun genel öz-yeterlik ölçeğinin başlama alt boyutu $(\mathrm{r}=-.32)$, yılmama alt boyutu $(\mathrm{r}=-.33)$ ve toplam puanı ile $(\mathrm{r}=-.34)$ orta düzeyde, 1 srar alt boyutu ile $(\mathrm{r}=-.15)$ düşük düzeyde negatif yönde bir ilişkisinin olduğu; kritize edilme alt boyutunun genel öz-yeterlik ölçeğinin başlama alt boyutu $(\mathrm{r}=-.31)$ ve toplam puanı ile $(\mathrm{r}=-.31)$ orta düzeyde, y1lmama alt boyutu $(\mathrm{r}=-.28)$ ve 1 srar alt boyutu ile $(\mathrm{r}=-.18)$ düşük düzeyde negatif yönde bir ilişkisinin olduğu; değersizlik alt boyutunun genel öz-yeterlik ölçeğinin başlama alt boyutu ( $\mathrm{r}=-.42)$, yılmama alt boyutu $(\mathrm{r}=-.43)$ ve toplam puanı ile $(\mathrm{r}=-.45)$ orta düzeyde, 1srar alt boyutu ile ( $\mathrm{r}=-.18$ ) düşük düzeyde negatif yönde bir ilişkisinin olduğu; sosyal kayg1 ölçeğinin toplam puanında ise genel öz-yeterlik ölçeğinin başlama alt boyutu $(r=-.40)$, yılmama alt boyutu $(\mathrm{r}=-.40)$ ve toplam puanı ile $(\mathrm{r}=-.42)$ orta düzeyde, 1 srar alt boyutu ile $(\mathrm{r}=-.16)$ düşük düzeyde negatif yönde bir ilişkisinin olduğu belirlenmiştir. Sosyal kaygı ölçeği ile genel öz-yeterlik ölçeğinden elde edilen puanlar arasında negatif yönde ve toplam puanlar açısından orta düzeyde bir ilişkinin belirlenmiş olması öğrencilerin öz-yeterlik düzeyleri yükseldikçe sosyal kaygı düzeylerinin azaldığı şeklinde yorumlanabilir.

\section{SONUÇ, TARTIŞMA VE ÖNERILER}

Ölçeklerden elde edilen puan ortalamalarına bakıldığında; öğrencilerin sosyal kaygılarının ölçeğin tüm alt boyutlarında ve toplam puanda orta düzeyde olduğu; genel öz-yeterlik puanlarının ise ölçeğin tüm alt boyutlarında ve toplam puanda yüksek düzeyde olduğu görülmektedir. Altınay-Bor (2018) tarafından yapılan çalışmadan elde edilen bulgularda öğrencilerin sosyal kaygı düzeylerinin orta düzeyde olduğu tespit edilmiştir. Arslan (2017a, 2017b) tarafından yapılan çalışmalarda da bu çalışma ile uyumlu olarak öğrencilerin öz-yeterlik algılarının yüksek düzeyde olduğu bulgusuna ulaşılmıştır. Öz-yeterlik düzeyi yüksek olan bireylerin düşük olan bireylere göre daha başarılı oldukları yapılan çalışmalarla da desteklenmiştir. Akar'ın (2008) çalışmasında öz-yeterlik düzeyi yüksek olan öğrencilerin düşük olan öğrencilere göre ilkokuma yazmada daha başarıllı oldukları belirlenmiştir.

SHMYO öğrencilerin cinsiyet değişkeni açısından sosyal kaygı düzeyleri ve genel öz-yeterlik algılarına ilişkin puanlarının ölçeklerin toplam ve alt boyutlarına ilişkin puanlarda anlamlı farklılık göstermediği tespit edilmiştir. Alemdağ ve Öncü (2015) tarafından üniversite öğrencilerine yönelik yapılan çalışma sonuçlarında öğrencilerin sosyal kaygılarının bu çalışmayla uyumlu olarak cinsiyet değişkeni açısından anlamlı farklılık göstermediği belirlenmiştir. İzgiç, Akyüz, Doğan ve Kuğu'nun (2000) üniversite düzeyinde yaptığı sosyal kaygının yaygınlığını belirlenmesinin amaçlandığı araştırma bulgularında, sosyal kaygının kız öğrencilerde erkek öğrencilere göre daha yaygın olarak görüldüğü belirlenmiştir. Akbaş ve Çelikkaleli (2006) tarafindan üniversite öğrencilerine yönelik yapılan araştırmada elde edilen sonuçların bu çalışmayla paralellik gösterdiği ve cinsiyet değişkeninin öğrencilerin öz-yeterlik algılarında anlamlı farklılık oluşturmadığı sonucuna ulaşılmıştır. Alanyazında öz-yeterlik algısının cinsiyet değişkeni açısından anlamlı farklılık bulunmayan çalışmaların (Akkuzu \& Akçay, 2012; İkiz \& Yörük, 2013) yanı sıra bu sonuçlarla çelişen çalışmalar (Jones \& Wheatley, 1990) bulunmaktadır. Cinsiyet değişkeni açısından anlamlı farklılığın bulunduğu çalışmalarda genel olarak geleneksel kadın algısının öne sürüldüğü; anlamlı farklılığın bulunmadığı çalışmalarda ise değişen dünya ve yaşam şartlarında kadınların toplumsal rollerinin de değişmesi, kadınların sosyal alanlarda geçmişe göre daha fazla öne çıkarak kendilerini güvenle ifade edebilen bireyler haline gelmelerinin belirleyici etken olduğu belirtilmektedir. Bir diğer etkenin de kadınların erkeklerle eşit eğitim almaları olduğu ve bu doğrultuda benlik saygılarını daha sağlam oluşturabildikleri söylenmektedir (Akbaş \& Çelikkaleli, 2006). Bu doğrultuda cinsiyetler arasındaki farklılık, çalışmanın yapıldığı grubun yaşam standartlarıyla bağlantılı olmaktadır. 
SHMYO öğrencilerinin sosyal kaygı düzeylerine ilişkin puan ortalamalarının gelir düzeyi değişkenine göre ölçeğin toplam ve alt boyutlarında anlamlı şekilde farklılaştığı görülmektedir. Anlamlı farklılığın hangi gruplar arasında olduğunun belirlenmesi amacıyla yapılan LSD analiz sonucuna göre ölçeğin kaçınma, değersizlik ve toplam puanında "íyi-Orta" grupları arasında iyi lehine; kritize edilme alt boyutunda "İyi-Orta" ve "İyi-Düşük" grupları arasında iyi lehine anlamlı farklılığın olduğu belirlenmiştir. Ölçeğin toplam puanına bakıldığında gelir düzeyi değişkeni açısından sosyal kaygısı en düşük olan grubun iyi en yüksek grubun ise orta olduğu görülmektedir. İzgiç vd. (2000) tarafından yapılan araştırma bulgularında sosyal kaygıyı en yoğun yaşayan grubun düşük gelir düzeyine sahip öğrenciler olduğu tespit edilmiştir. Ayan vd.'nin (2013) yaptıkları çalışma sonuçlarında gelir düzeyi sosyal kaygı üzerinde anlamlı farklılık oluşturmamakla birlikte katılımcıların gelir düzeyleri yükseldikçe sosyal kaygı düzeylerinin düştüğü saptanmıştır. Elde edilen bulguların bireyin ekonomik anlamda kendini rahat hissetmesinin sosyal alanlarda kendine daha çok güvenmesini desteklediği şeklinde yorumlanabileceği ifade edilmektedir.

SHMYO öğrencilerinin genel öz-yeterlik düzeylerine ilişkin puan ortalamalarının ölçeğin başlama alt boyutunda anlamlı şekilde farklılaştı̆̆1; diğer alt boyutlar ve toplam puanda ise anlamlı farklılık bulunmadığ 1 görülmektedir. Anlamlı farklılığın hangi gruplar arasında olduğunun belirlenmesi amaciyla yapılan LSD analiz sonucuna göre farklılı̆̆ın "Çok iyi-İyi" ve "Çok iyi-Orta" grupları arasında çok iyi grubu aleyhine olduğu saptanmıştır. Ölçeğin toplam puanına bakıldığında gelir düzeyi değişkeni açısından genel öz-yeterlik algısı en yüksek olan grubun iyi en düşük grubun ise çok iyi olduğu görülmektedir. İkiz ve Yörük'ün (2013) çalışmasında öğrencilerin gelir düzeylerinin öz-yeterlik algıları üzerinde belirleyici bir değişken olmadığı tespit edilmiştir.

SHMYO öğrencilerinin ikamet yeri değişkenine göre sosyal kaygılarının tüm alt boyut ve toplam puan ortalamalarına göre anlamlı farklılık gösterdiğgi tespit edilmiştir. Anlamlı farklılığın kaçınma ve kritize etme alt boyutlarında "Köy-Şehir" ve "Köy-Büyükşehir" grupları arasında köy aleyhine; 1srar alt boyutu ve toplam puanda "Köy-İlçe”, "Köy-Şehir" ve "Köy-Büyükşehir" grupları arasında köy aleyhine olduğu saptanmıştır. Toplam puan açısından bakıldığında en düşük sosyal kaygı puanına büyükşehirde yaşayan öğrencilerin en düşük kaygı puanına ise köyde yaşayan öğrencilerin sahip oldukları görülmektedir. Öğrencilerin sosyal kaygılarının ikamet ettikleri yer bağlamında nüfusu kalabalık olan yerleşim alanlarından nüfusu az olan yerleşim alanlarına doğru yapılan sıralamaya göre artış gösterdiği görülmektedir. İzgiç ve diğ.'nin (2000) yaptıkları araştırma bulgularında bu çalışmada elde edilen bulgularla benzer sonuçlar elde edilmiştir. Sosyal kaygı puanı en yüksek olan öğrencilerin köy yerleşim yerinde yaşayan öğrenciler olduğu saptanmıştır. Ayan vd. (2013) tarafindan yapılan çalışma sonuçları incelendiğinde yerleşim yerinin bireyin sosyal kaygı düzeyinde etkili olduğu ve şehirleşme düzeyi yükseldikçe sosyal kayg1 düzeyinde de düşme görüldüğü belirlenmiştir. Köy yerleşim alanından büyükşehir yerleşim alanına doğru bireyin çevresindeki insan sayısı artmakta ve dolayısıyla daha farklı sosyal ortamlarda bulunma şansı yakalamaktadır. Bu durum farklı sosyal deneyimler edinmesini sağlamakta ve dolayısıyla yaşadığı sosyal kaygı üzerinde olumlu etki oluşturmaktadır.

SHMYO'da öğrenim görmekte olan öğrencilerin genel öz-yeterlik algılarının ikamet yeri değişkeni açısından ölçeğin alt boyutları ve toplam puan ortalamalarında anlamlı farklılık oluşturmadığı görülmektedir. Toplam puan açısından öğrencilerin genel öz-yeterlik algı düzeylerinin en yüksek büyükşehirde en düşük ise şehirde yaşayan öğrencilerde bulunduğu tespit edilmiştir. İkiz ve Yörük'ün (2013) üniversite düzeyinde yaptığı araştırmadan elde edilen bulgular bu çalışmayla uyumluluk göstermektedir.

Öğrencilerin mezun olunan okul türü değişkenine göre ölçeğin kaçınma ve kritize edilme alt boyutlarında anlamlı farklılık olduğu, değersizlik alt boyutu ve toplam puanda ise anlamlı farkl11ık olmadığ 1 tespit edilmiştir. Farklılığın kaçınma alt boyutunda "Genel Lise-İmam Hatip Lisesi” "arasında genel lise lehine; "Anadolu Lisesi-Genel Lise" ve "Anadolu Lisesi-Sağlık Meslek Lisesi”" arasında 
Anadolu lisesi aleyhine olduğu belirlenmiştir. Toplam puan açısından öğrencilerin sosyal kayg1 düzeylerine bakıldığında en yüksek kaygı düzeyinin imam hatip lisesi mezunu öğrencilerde en düşük kayg1 düzeyinin ise genel lise mezunu öğrencilerde olduğu görülmektedir. Öğrencilerin genel özyeterlik düzeylerinin mezun oldukları lise türü açısından ölçeğin yılmama alt boyutunda "Sağglk Meslek Lisesi-Genel Lise" ve "Sağllk Meslek Lisesi-Anadolu Lisesi" arasında sağlık lisesi lehine anlamlı farklılık gösterdiği, diğer alt boyutlar ve toplam puanda ise anlamlı farkl1lık göstermediği belirlenmiştir. Toplam puan açısından değerlendirildiğinde genel öz-yeterlik algısı en yüksek olan grubun sağlık meslek lisesinden mezun olan öğrencilerin, en düşük olan grubun ise genel liseden mezun olan öğrencilerin oluşturduğu saptanmıştır. Alanyazında üniversite düzeyinde yapılan çalışmalar incelendiğinde; bu çalışmada elde edilen bulgularla uyumlu olarak öğrencilerin öz-yeterlik algılarının mezun oldukları lise türüne göre anlamlı farklılığın olduğu çalışmalar (Akkuzu \& Akçay) bulunmasının yanı sıra bu çalışmayla çelişerek anlamlı farklılık belirlenmeyen çalışmaların da (Çimen, 2007; Ekici, 2008; Gençtürk \& Memiş, 2010) bulunduğu görülmektedir. Öğrencilerin mezun oldukları liselerde karşılaştıkları sosyal ortamların sosyal becerilerini ve dolayısıyla öz-yeterlik algılarını etkileyeceği düşünülmektedir.

SHMYO'da öğrenim görmekte olan öğrencilerin branş değişkeni açısından sosyal kaygı puanlarının ölçeğin tüm alt boyutlarında ve toplam puanında anlamlı farklılık oluşturduğu belirlenmiştir. Anlamlı farklılığın olduğu grupların belirlenmesi amacıyla yapılan LSD testinden elde edilen bulgulara göre ölçeğin kaçınma alt boyutunda "Tıbbi Dokümantasyon ve Sekreterlik-Eczane Hizmetleri”, "Çocuk Gelişimi-Eczane Hizmetleri”, "Tibbi Görüntüleme Teknikleri--Eczane Hizmetleri", "Yaşlı Bakımı-Eczane Hizmetleri" arasında eczane hizmetleri lehine, "Yaşlı Bakımı-İlk ve Acil Yardım" ve "Yaşlı Bakımı-Optisyenlik" arasında yaşlı bakımı aleyhine; kritize edilme alt boyutunda "Tıbbi Dokümantasyon ve Sekreterlik-Illk ve Acil Yardım" ve "Yaşlı Bakımı-İlk ve Acil Yardım" arasında ilk ve acil yardım lehine; değersizlik alt boyutunda "Tlbbi Dokümantasyon ve Sekreterlik-Ilk ve Acil Yardım", "Tıbbi Dokümantasyon ve Sekreterlik-Eczane Hizmetleri" arasında tıbbi dokümantasyon ve sekreterlik aleyhine, "Ilk ve Acil Yardım-Odyometri", "Eczane HizmetleriOdyometri" arasinda odyometri aleyhine; toplam puanda ise "Fizyoterapi-IIlk ve Acil Yardım", "Tibbi Dokümantasyon ve Sekreterlik-Illk ve Acil Yardım", "Çocuk Gelişimi-Illk ve Acil Yardım", "Yaşlı Bakımı-Illk ve Acil Yardım", "Odyometri-Illk ve Acil Yardım" arasında ilk ve acil yardım lehine, "Tibbi Dokümantasyon ve Sekreterlik-Eczane Hizmetleri", "Yaşlı Bakımı-Eczane Hizmetleri", "OdyometriEczane Hizmetleri" arasında eczane hizmetleri lehine, "Yaşlı Bakımı-Optisyenlik" arasında optisyenlik lehine anlamlı farklılığın olduğu saptanmıştır. Toplam puan açısından bakıldığında en yüksek sosyal kaygı puanına odyometri bölümünde öğrenim gören öğrencilerin en düşük sosyal kayg1 puanına ise eczane hizmetleri bölümünde eğitim gören öğrencilerin sahip oldukları görülmektedir. Alemdağ ve Öncü (2015) tarafından yapılan araştırma bulgularında öğrencilerin öğrenim gördükleri branş açısından sosyal kaygı puanlarında anlamlı derecede farklılaşma belirlenmemiştir.

SHMYO öğrencilerinin branş değişkenine göre genel öz-yeterlik algılarına ilişkin puanlarının ölçeğin tüm alt boyutlarında ve toplam puanda anlamlı farklılık gösterdiği belirlenmiştir. Anlamlı farklılığın ölçeğin başlama alt boyutunda ve toplam puanına "Fizyoterapi-Tibbi Dokümantasyon ve Sekreterlik", "Fizyoterapi-Tibbi Görüntüleme Teknikleri", "Fizyoterapi-Yaşlı Bakımı", "FizyoterapiOdyometri", "Fizyoterapi-Optisyenlik" arasında fizyoterapi lehine; "ilk ve Acil Yardim-Tibbi Görüntüleme Teknikleri", "ilk ve Acil Yardım-Yaşlı Bakımı", "Illk ve Acil Yardım-Tıbbi Dokümantasyon ve Sekreterlik", "Illk ve Acil Yardım-Odyometri”" arasında ilk ve acil yardım lehine; "Çocuk Gelişimi-Yaşlı Bakımı", "Çocuk Gelişsimi-Odyometri”, "Çocuk Gelişimi-Tıbbi Görüntüleme Teknikleri” "arasında çocuk gelişimi lehine olduğu görülmektedir. Ölçeğin yılmama alt boyutunda "Fizyoterapi-Tıbbi Görüntüleme Teknikleri", "Eczane Hizmetleri- Tıbbi Görüntüleme Teknikleri" arasında tıbbi görüntüleme teknikleri aleyhine; "Illk ve acil yardım-Tibbi Dokümantasyon ve Sekreterlik", "Illk ve acil yardım-Yaşlı Bakımı", "Illk ve acil yardım-Odyometri”, arasında ilk ve acil 
yardım lehine; ısrar alt boyutunda "Fizyoterapi-Tibbi Dokümantasyon ve Sekreterlik", "FizyoterapiTibbi Görüntüleme Teknikleri”, "Fizyoterapi-Yaşll Bakımı", "Fizyoterapi-Eczane Hizmetleri" arasında fizyoterapi lehine anlamlı farklılı̆̆ın olduğu tespit edilmiştir. Ölçekten alınan toplam puana göre en yüksek öz-yeterlik algısına fizyoterapi bölümü, en düşük öz-yeterlik algısına ise odyometri bölümünde eğitim gören öğrencilerin sahip oldukları görülmektedir. Çimen (2007) tarafindan yapılan araştırma bulgularına göre branş değişkeninin öz-yeterlik algısı üzerinde anlamlı farklılık oluşturduğu belirlenmiştir.

Öğrencilerin sosyal kaygıları ile genel öz-yeterlik algıları arasındaki ilişki düzeyinin ve ilişki yönünün belirlenmesi için yapılan pearson koralesyon analizi sonuçlarına göre; sosyal kaygı ölçeğinin kaçınma alt boyutunun genel öz-yeterlik ölçeğinin başlama, yılmama alt boyutu ve toplam puanı ile orta düzeyde, 1srar alt boyutu ile düşük düzeyde negatif yönde bir ilişkisinin olduğu; kritize edilme alt boyutunun genel öz-yeterlik ölçeğinin başlama alt boyutu ve toplam puanı ile orta düzeyde, yılmama alt boyutu ve 1srar alt boyutu ile düşük düzeyde negatif yönde bir ilişkisinin olduğu; değersizlik alt boyutunun genel öz-yeterlik ölçeğinin başlama, yılmama alt boyutları ve toplam puanı ile orta düzeyde, 1srar alt boyutu ile düşük düzeyde negatif yönde bir ilişkisinin olduğu; sosyal kaygı ölçeğinin toplam puanında ise genel öz-yeterlik ölçeğinin başlama ve yılmama alt boyutları ve toplam puanı ile orta düzeyde, 1srar alt boyutu ile düşük düzeyde negatif yönde bir ilişkisinin olduğu belirlenmiştir. Sosyal kaygı ölçeği ile genel öz-yeterlik ölçeğinden elde edilen puanlar arasında negatif yönde ve toplam puanlar açısından orta düzeyde bir ilişkinin belirlenmiş olması öğrencilerin öz-yeterlik düzeyleri yükseldikçe sosyal kaygı düzeylerinin azaldığı şeklinde yorumlanabilir.

Sosyal kaygının öz-yeterlikle ilişkisini belirlemeye yönelik başka bir çalışmaya rastlanmamıştır. Sosyal kaygının alanyazında olumlu ya da olumsuz yöndeki farklı etkenlerle ilişkisine bakılan çalışmalar bulunmaktadır. Altınay-Bor'un (2018) yaptığı çalışmada sosyal kaygı ile sosyal ortamlardaki gelişmeleri kaçırma korkusu arasında pozitif, sosyal yetkinlik ile negatif yönde anlamlı bir ilişkinin olduğu tespit edilmiştir. Sosyal kaygının hayatın pek çok alanında olumsuz etkisinin olduğu gerçeğinden hareketle yapılan bir diğer çalışma da Greca ve Lopez'in (1998) sosyal kaygının arkadaş ilişkilerine etkinin belirlenmesinin amaçlandığı çalışmadır. Çalışmadan elde edilen bulgular sosyal kaygı düzeyi yükseldikçe öğrencilerin arkadaş ilişkilerinde kabul düzeylerinin azaldığı yönündedir. Burada en önemli etkenin sosyal kaygı taşıyan bireylerin yargılanma korkusuyla diğer bireylerle daha az etkileşimde bulunmaları ve paylaşım yapmaları olduğu belirtilmektedir. Bireyin hissettiği sosyal kayg1 üzerinde içinde yetiştiği ailenin ve çevrenin etkisi oldukça büyüktür. Onaylandığı ve etkin iletişim ortamlarının kurulduğu sosyal çevrelerde yetişen bireylerde daha düşük düzeyde sosyal kaygı görülmektedir. Erkan (2002) tarafından yapılan araştırmada öğrencilerin sosyal kayg1 düzeylerinin koruyucu ve otoriter ailelerde yetişenlerde yüksek, demokratik ailelerde yetişenlerde ise düşük düzeyde olduğu belirlenmiştir. Ailenin çocuğu olası tehlikelerden korumak adına sürekli kalkan vazifesi görmesi ya da tam tersi olarak bask1 uygulanması ve söz hakk1 verilmemesi onun gerçek hayat ve sosyal ortamlarda tek başına kendini ifade etmeye yönelik kayg1 yaşamasına neden olmaktadır. Baltacı (2010) tarafından yapılan çalışmada da benzer bulgular elde edilmiş, demokratik tutuma sahip ailelerin çocuklarının daha az sosyal kaygı yaşadıkları belirlenmiştir. Anne babanın çocuğa yönelik tutarsız ve samimiyetsiz davranışları da onun sosyal kaygı yaşamasında önemli bir etken olmaktadır (Mehtalia \& Vankar, 2004). Sosyal kaygının düzeyinin bireyin yetiştiği ailede duygusal yakınlık derecesi arttıkça azaldığı da yapılan bir diğer çalışmada belirlenmiştir (Xu, Ni, Ran \& Zhang, 2017). Ayrıca ebeveynleri sosyal kaygı taşıyan bireylerin sosyal kaygı düzeylerinin diğer bireylere oranla daha yüksek olduğu görülmektedir (Festa \& Ginsburg, 2011). Yapılan çalışmalarda elde edilen bulgular doğrultusunda bireyin dünyaya geldiği andan itibaren karşılaştığ kişiler ve içinde yetiştiği çevrenin sosyal kaygı düzeyi üzerinde etkisi bulunduğu, ailesiyle olan duygudaşlık derecesinin de düşünce, davranış ve kişiliğini etkilediği görülmektedir (Erdoğan \& Uçukoğlu, 2011). 
Bireyin yaşadığı sosyal kaygının azaltılmasında öncelikle bilinçli aile ve çevrenin önemli olduğu gerçeğinden hareketle anne baba eğitimlerine önem verilmelidir. Her düzey ve yaştaki öğrencilerin sosyal kaygı düzeyinin belirlenmesi öğrencilerin sosyal kaygı yaşama problemlerine ilişkin olarak önceden önlem alınması ya da var olan sosyal kaygının azaltılması ile yapılacak çalışmalara 1şık tutacaktır. Var olan sosyal kaygının azaltılması ile ilgili farklı çalışmalar yapılabilir. Wong ve Sun (2006) tarafindan yapılan çalışmada öğrencilerin sosyal kaygı düzeylerini azaltmak için bilişsel davranışçı grup terapisi uygulanmış ve başarılı sonuçlar elde edilmiştir. Koçak (2001) da öğrencilerin sosyal kaygılarını azaltmak için bilişsel beceri temelli eğitim programını uygulamış ve olumlu sonuçlara ulaşmıştır. Buradan hareketle sosyal kaygı yaşayan öğrencilere farklı alanlarda beceri eğitiminin verilmesinin onların ortaya bir ürün ya da davranış koymaları açısından kendilerini daha güvenli hissedecekleri ve dolayısıyla sosyal ortamlarda daha rahat olabilecekleri düşünülmektedir. Öğretmenlerin sosyal kaygı yaşayan öğrencilerin özelliklerini bilmeleri ve onları kademeli olarak sosyal ortamlarda görevlendirmeleri gerekmektedir. Bu konuda öğretmenlerle rehberlik birimleri arasında koordinasyonlu çalışmaların yapılması gerektiği düşünülmektedir.

\section{KAYNAKÇA}

Akar, C. (2008). Öz-yeterlik inancı ve ilkokuma yazmaya etkisi. Uşak Üniversitesi Sosyal Bilimler Dergisi, 1(2), 185-198.

Akbaş, A., \& Çelikkaleli, Ö. (2006). Sınıf öğretmeni adaylarının fen öğretimi özyeterlik inançlarının cinsiyet, öğrenim türü ve üniversitelerine göre incelenmesi. Mersin Üniversitesi Eğitim Fakültesi Dergisi, 2(1), 98-110.

Akkuzu, N., \& Akçay, H. 2012). Kimya öğretmen adaylarının öz yeterlik inançlarının farklı değişkenler açısından incelenmesi (dokuz eylül üniversitesi örneği). Kuram ve Uygulamada Ĕ̈itim Bilimleri, 12, 2195-2216.

Aksu, H. H. (2008). Öğretmen adaylarının matematik öğretimine yönelik öz-yeterlilik inançları. Abant İzet Baysal Üniversitesi Ĕ̈itim Fakültesi Dergisi, 8(2), 161-170.

Alemdağ, S., \& Öncü, E. (2015). Öğretmen adaylarının fiziksel aktiviteye katılım ve sosyal görünüş kaygilarının incelenmesi. International Journal of Science Culture and Sport, 3(3), 287-300.

Altınay-Bor, H. (2018). Ergenlerde sosyal medyaya yönelik tutum, sosyal medya kullanımında gelişmeleri kaçırma korkusu ve sosyal kaygı arasındaki ilişkiler. Yayınlanmamış Yüksek Lisans Tezi. İstanbul Üniversitesi Eğitim Bilimleri Enstitüsü, İstanbul.

Altıntaş, E., \& Kaya, H. (2012). Fen bilgisi öğretmen adaylarının drama yöntemiyle fen ve teknoloji dersinin işlenmesine yönelik öz-yeterlik ve tutumları. Erciyes Üniversitesi Fen Bilimleri Enstitüsü Fen Bilimleri Dergisi, 28(4), 287-295.

Anthony, M. M., \& Swinson, R. P. (2000). The shyness and social anxiety workbook. Oakland: New Harbinger.

Arslan, A. (2017a). Ortaokul öğrencilerinin okuma kaygıları ve akademik özyeterlik inançlarının çeşitli değişkenler açısından incelenmesi. e-Kafkas Eğitim Araştırmaları Dergisi, 4(3), 30-44.

Arslan, A. (2017b). Ortaokul öğrencilerinin dinleme kaygıları ve akademik özyeterlik inançlarının çeşitli değişkenler açısından incelenmesi. International e-Journal of Educational Studies (IEJES), 1(1), 12-31.

Arslan, A. (2018a). Ortaokul öğrencilerinin konușma kaygıları ve akademik öz-yeterlik inançlarının çeşitli değişkenler açısından incelenmesi. International e-Journal of Educational Studies (IEJES), 2(1), 26-43. DOI: 10.31458/iejes.399014

Arslan, A. (2018b). Ortaokul öğrencilerinin yazma kaygıları ve akademik özyeterlik inançlarının çeşitli değişkenler açısından incelenmesi. Abant İzzet Baysal Üniversitesi Eğitim Fakültesi Dergisi, 18(3), 1286-1312.

Aşkar, P., \& Umay, A. (2001). İlköğretim matematik öğretmenliği öğrencilerinin bilgisayarla ilgili özyeterlik algıs1. Hacettepe Üniversitesi Ĕ̌itim Fakültesi Dergisi, 21, 1-8.

Baltacı, Ö. (2010). Üniversite ögrencilerinin sosyal kaygı, sosyal destek ve problem çözme yaklaşımları arasındaki ilişkinin incelenmesi. Yayınlanmamış Yüksek Lisans Tezi. Selçuk Üniversitesi Eğitim Bilimleri Enstitüsü, Konya. 
Bandura, A. (1986). Social foundations of thought and action: A social cognitive theory. Englewood Cliffs, NJ, US: Prentice-Hall, Inc.

Bandura, A. (1997). Self-efficacy: The exercise of control. New York: Freeman.

Baumeister, R. F., \& Tice, D.M. (1990). Anxiety and social exclusion. Journal of Social and Clinical Psychology, 9, 165-195.

Beck, A. T. (2005). Bilişsel terapi ve duygusal bozukluklar. A. Türkcan (Çev.). İstanbul: Litera Yayinc1lik.

Cassidy, S., \& Eachus, P. (2002). Developing the computer user self-efficacy (CUSE) scale: Investigating the relationship between computer self-efficacy, gender and experience with computers. Journal of Educational Computing Research, 26(2), 133-153.

Çimen, S. (2007). İlköğretim ögretmenlerinin tükenmişlik yaşantıları ve yeterlik algıları. Yayınlanmamış Yüksek Lisans Tezi. Kocaeli Üniversitesi Sosyal Bilimler Enstitüsü, Kocaeli.

Davison, C. G., \& Neale, J.M. (2004). Anormal psikoloji. İ. Dağ (Çev.) Ankara: Türk Psikoloji Derneği Yayınları.

Dunlop, B. W., Papp, L., Garlow, S. J., Weiss, P. S., Knight, B. T., \& Ninan, P. T. (2007). Tiagabine for social anxiety disorder. Human Psychopharmacology: Clinical and Experimental, 22(4), 241-244.

Ekici, G. (2008). Sınıf yönetimi dersinin öğretmen adaylarının öğretmen öz-yeterlik algı düzeyine etkisi. Hacettepe Üniversitesi Eğitim Fakültesi Dergisi, 35(35), 98-110.

Erdoğan, Ö., \& Uçukoğlu, H. (2011). İlköğretim okulu öğrencilerinin anne-baba tutumu algıları ile atılganlık ve olumsuz değerlendirilmekten korkma düzeyleri arasındaki ilişkiler. Kastamonu Eğitim Dergisi 19(1), 51-72.

Erkan, Z. (2002). Ergenlerin sosyal kaygı düzeyleri, ana-baba tutumlarl ve ailede görülen risk faktörleri üzerine bir çalışma. Yayınlanmamış Doktora Tezi. Çukurova Üniversitesi, Sosyal Bilimler Enstitüsü, Adana.

Erözkan A. (2004). Üniversite öğrencilerinin sınav kaygısı ve başa çıkma davranışları. Muğla Üniversitesi Sosyal Bilimler Enstitüsü Dergisi, 13-38.

Festa, C. C., \& Ginsburg, G. S. (2011). Parental and peer predictors of social anxiety in youth. Child Psychiatry \& Human Development, 42(3), 291-306.

Greca, A. M., \& Lopez, N. (1998). Social anxiety among adolescents: linkages with peer relations and friendships. Journal of Abnormal Child Psychology, 26(2), 83- 94.

Hamarta, E. (2009). Ergenlerin sosyal kaygılarının kişilerarası problem çözme ve mükemmeliyetçilik açısından incelenmesi. İlkögretim Online 8(3), 729-740.

Işık, E. (1996). Somatoform bozukluklar, yapay bozukluklar, anksiyete bozuklukları. Ankara: Bask1 Kent Matbaa.

İkiz, F. E., \& Yörük, C. (2013). Öğretmen adaylarının öz-yeterlik düzeyleri ile aile işlevlerinin incelenmesi. Uşak Üniversitesi Sosyal Bilimler Dergisi, 6(1), 228-248.

İzgiç, F., Akyüz, G., Doğan, O., \& Kuğu, N. (2000). Üniversite öğrencilerinde sosyal fobi yaygınlığı. Anadolu Psikiyatri Dergisi, 1(4), 207-214.

Jones, M. G., \& Wheatley, J. (1990). Gender differences in teacher-student interactions in science classrooms. Journal of Research in Science Teach, 27(9), 861-874.

Koç, C., \& Arslan, A. (2015). Ortaokul öğrencilerinin başarı yönelimlerinin ve okuma stratejileri bilişüstü farkındalıklarının incelenmesi. Pegem Eğitim ve Öğretim Dergisi, 5(5), 485. DOI: 1.14527/pegegog.2015.027

Koçak, A. (2001). Sosyal kaygıyla başa çıkma programının lise öğrencilerinin sosyal kaygı düzeylerine etkisi. Yayınlanmamış Yüksek Lisans Tezi. Gazi Üniversitesi Eğitim Bilimleri Enstitüsü, Ankara.

Leahy, R., \& Holland, S. (2009). Depresyon ve kaygı bozukluğu tedavi planları ve girişimleri. S. Alsan, E. Köroğlu, H. Türkçapar (Çev.). (1. Baskı). Ankara: HYB Yayınları.

Mehtalia K., \& Vankar, G. K. (2004). Social anxiety adolescents. Indian Journal of Psychiatry, 46(3), 221-227.

Özbay, Y., \& Palancı, M. (2001). Sosyal kaygı ölçeği: Geçerlik ve güvenirlik çalışması. VI. Ulusal Psikolojik Danışma ve Rehberlik Kongresi, 5-7.

Pajares, F. (2006). Self-efficacy during childhood and adolescence. F. Pajares, T. Urdan (Ed.), In selfefficacy beliefs of adolescents (339-367). Greenwich, CT: Information Age Publishing. 
Pajares, F., \& Schunk, D. H. (2004). Self-efficacy in education revisited. Empirical and applied evidence. Etten, V. S. \& McInerney, D. M. (Ed.). In big theories revisited. Scottsdale: Information Age Publishing.

Sherer, M., Maddux, J. E., Mercandante, B., Prentice-Dunn, S., Jacobs, B., \& Rogers, R. W. (1982). The self-efficacy scale: Construction and validation. Psychological reports, 51(2), 663-671.

Sönmez, V., \& Alacapınar, F. G. (2011). Bilimsel araştırma yöntemleri (1. Bask1). Ankara: Anı Yayincilik.

Temel, F., \& Aksoy, A. (2001). Ergen ve gelişimi yetişkinliğe ilk adım. (1. Baskı). Ankara: Nobel Yayınları.

Wong, D. F. K., \& Sun, S. Y. K. (2006). A preliminary study of the efficacy of group cognitivebehavioral therapy for people with social anxiety in hong kong. Hong Kong J Psychiatry, 16(2), 50-56.

Xu, J., Ni, S., Ran, M., \& Zhang, C. (2017). The relationship between parenting styles and adolescents' social anxiety in migrant families: A study in Guangdong, China. Frontiers in Psychology, 8, 1-7.

Yavuzer, Y., \& Koç, M. (2002). Eğitim fakültesi öğrencilerinin öğretmen yetkinlikleri üzerinde bir değerlendirme. Niğde Üniversitesi Ĕ̈itim Fakültesi Dergisi, 1(1), 35- 43.

Yıldırım, F., \& İlhan, İ. Ö. (2010). Genel öz yeterlilik ölçeği Türkçe formunun geçerlilik ve güvenilirlik çalışması. Türk Psikiyatri Dergisi, 21(4), 301-308. 